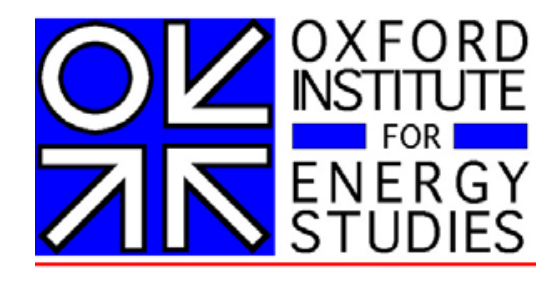

\title{
Is There A Rationale for the Continuing Link to Oil Product Prices in Continental European Long-Term Gas Contracts?
}

\section{JONATHAN STERN}

April 2007

NG 19 
The contents of this paper are the author's sole responsibility. They do not necessarily represent the views of the Oxford Institute for Energy Studies or any of its Members.

Copyright (C) 2007

\section{Oxford Institute for Energy Studies}

(Registered Charity, No. 286084)

This publication may be reproduced in part for educational or non-profit purposes without special permission from the copyright holder, provided acknowledgment of the source is made. No use of this publication may be made for resale or for any other commercial purpose whatsoever without prior permission in writing from the Oxford Institute for Energy Studies.

ISBN

$1-901795-59-4$

978-1-901795-59-2 


\section{ACKNOWLEDGEMENTS}

Katja Yamfimava prepared all of the statistics on oil and oil products which appear in the paper. Patrick Heather and David Long provided much useful information and many insights on gas and oil products trading. Patrick Heren and Louise Boddy shared with me their views on the development of NBP and Continental European gas hubs. The January 2007 OIES sponsors' meeting generated many useful comments and suggestions. Gas Matters and Gas Strategies Online kindly allowed me to use Charts 6 and 7, and Heren Energy Charts 8 and 9. My grateful thanks to all of them; I am solely responsible for what remains.

Jonathan Stern, February 2007 


\section{TABLE OF CONTENTS}

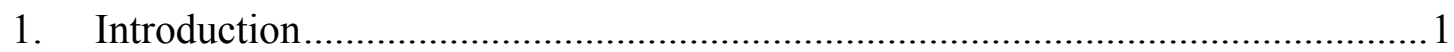

2. Oil product-linked gas prices: history and traditional justification ...................... 1

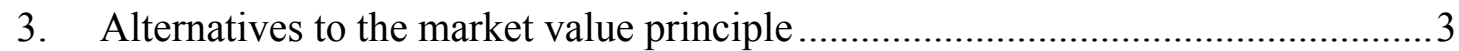

4. Continued relevance of oil product linkage in the $2000 \mathrm{~s}$.................................. 4

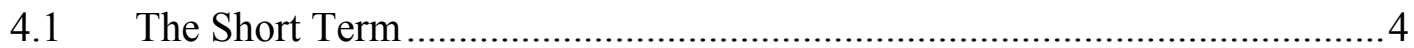

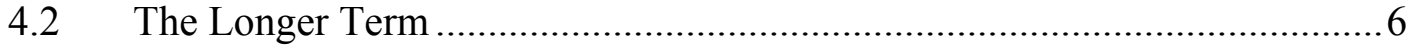

5. Continental European gas price indexation in 2004 ...........................................6

6. Gasoil and residual fuel oil consumption trends in Europe ...............................10

6.1 Shares of Gasoil and Fuel Oil in Stationary Energy Demand .....................11

6.2 Evidence of Gas to Oil Product Switching ............................................... 13

7. Gasoil and residual fuel oil price transparency and market liquidity ..................15

8. Alternatives to oil product indexation: towards gas indexed prices? .................. 17

9. Arguments for and against oil product-linked pricing ....................................2

9.1 Incumbent Perspectives: issues of market power ....................................22

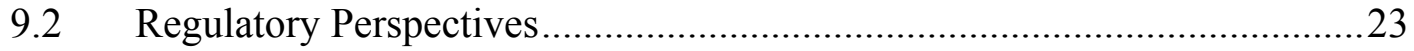

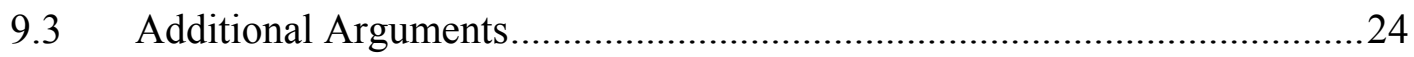

10. Will gas prices naturally follow oil prices in the absence of a formal index?.25

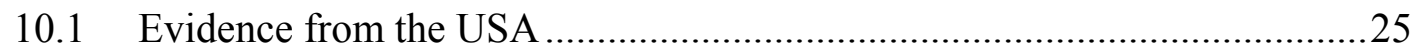

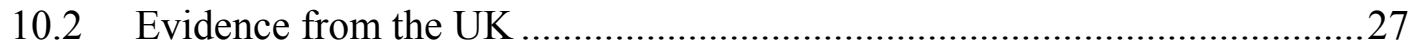

10.3 Evidence from Continental Europe ..........................................................29

11. What could be the determinants of future gas prices? ...................................30

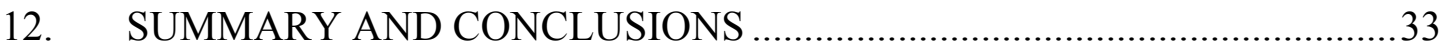

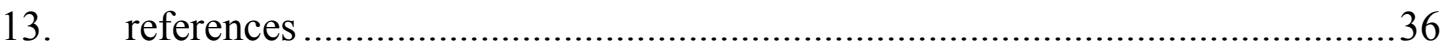

14. APPENDIX A: GASOIL AND FUEL OIL CONSUMPTION IN EUROPE

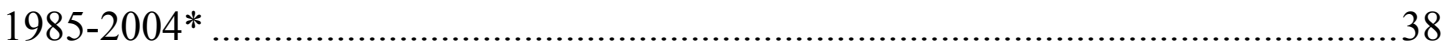

APPENDIX B: YEAR TO YEAR CHANGES IN GASOIL AND FUEL OIL CONSUMPTION IN EUROPE 1985-2004* 


\section{CHARTS AND TABLES}

Box 1: Evidence of Fuel Switching - The UK during Winter 2005-06 5

Chart 1: The Netback Market Value Concept................................................................

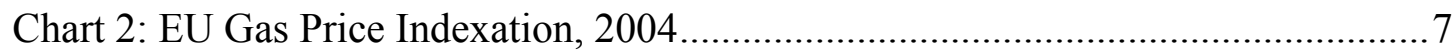

Chart 3: Gas Price Indexation for Different Producers and Exporters .......................... 8

Chart 4: Indexation in European Gas Contracts by Purchasing Region 2004. ..............9

Chart 5: Open Interest for ICE Gasoil Futures, 1999-2006 .......................................16

Chart 6: European Gas Market Hubs ......................................................................... 17

Chart 7: NBP Throughput, Trades and Churn, October 2004-October 2006 ..............18

Chart 8: Average Daily Volumes Traded on Continental European Gas Hubs, October

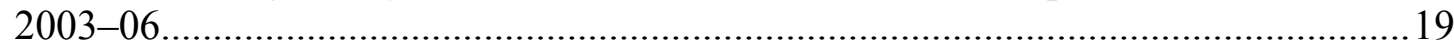

Chart 9: Churn Rate at European Gas Hubs, October 2006 ......................................20

Chart 10: WTI Crude Oil and Henry Hub Natural Gas Prices 1989-2005 .................26

Chart 11: UK Gas and International Oil Prices ....................................................2

Chart 12: Phases of UK Gas and Oil Price Linkage ...................................................29

Table 1: Shares of Crude Oil, Oil Product and Gas in the Gas Price Indexation of Exporting Countries, 2004. Percent ............................................................................. 9

Table 2: Shares of Crude Oil, Oil Product and Gas in Gas Price Indexation of

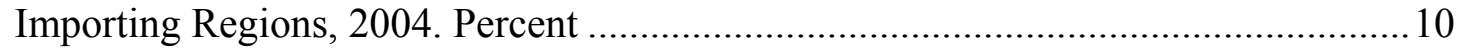

Table 3: Consumption of Gas/Diesel Oil in Stationary Sectors, 2004. Thousand Tons

Table 5: Share of Gas Oil in Total Energy Consumption of Stationary Sectors, 2004. Per Cent.

Table 6. Share of Residual Fuel Oil in Total Energy Consumption of Stationary Sectors, 2004. Percent.

Table 7: Share of Gas in Total Energy Consumption of Stationary Sectors, 2004.

Percent..... 13

Table 8: Gas/Diesel Oil and Residual Fuel Oil Demand in Transportation and Petrochemicals, 2004. Thousand Tons 


\section{INTRODUCTION}

This paper examines the rationale for the continuing linkage of European gas prices to oil product prices. With the passage of liberalisation and competition legislation by the EU and national governments, starting in the late 1990s, it was expected that prices would be determined by gas to gas competition, as happened in both North America and the UK in the 1980s and 1990s. However, in the 2000s, North American and UK gas prices regained a more immediate correlation with oil prices, while Continental European prices in long-term contracts have remained (predominantly) linked to oil products. A number of additional questions arising from the linkage between oil and gas prices - in particular whether prices of the two fuels tend towards a natural correlation irrespective of contractual relationships between market players are also examined. But the specific question which this paper addresses is whether there is still a rationale for gas prices to be largely indexed to oil product prices in European gas contracts and, if so, what is that rationale?

There are significant problems in obtaining data to carry out any rigorous examination of European gas contracts which are largely confidential, particularly in relation to pricing. Moreover, the issue of which products - and in which proportions - should be considered realistic substitutes for gas in national energy markets, remains subject to periodic renegotiation. Thus market players are unlikely to reveal their innermost thoughts on this subject and are most likely to advance positions that will maximise their financial returns in commercial negotiations.

\section{OIL PRODUCT-LINKED GAS PRICES: HISTORY AND TRADITIONAL JUSTIFICATION}

Since the beginning of the natural gas era in Europe, importers and exporters have based the trade on long-term contracts with an average duration of 20-25 years.

In the mid-1980s, three price principles were identified by the IEA: ${ }^{1}$

[these] have been applied or proposed at various times by various parties to the pricing of wholesale gas supplies to West European transmission companies. These principles may be summarised as suggesting that gas should be priced either:

- so as to be at or near parity with crude oil export prices, or

- so as to be competitive with the final consumer's alternative non-gas fuels or

- so as to reflect historic costs of gas production.

The second principle - that the price of gas should generally be competitive with the prices of alternative (non-gas) fuels - has been the most widely applied in Western Europe and this became known as the 'market value principle'. In addition, pricing

\footnotetext{
${ }^{1}$ IEA 1986, p.89

${ }^{2}$ It is worth stressing the geographical region of Western Europe because, prior to 1991, and the breakup of Comecon, prices of Soviet gas to the socialist countries in central/eastern Europe were set by a different mechanism.
} 
was in a process of change in the mid-1980s because of the volatility of oil prices. It was during this period that three-year price reviews were introduced into the majority of Continental European gas contracts.

The market value principle developed after the oil price increases of 1973-74 when the relative value of fuels competing with gas in the energy market became subject to major fluctuations. A documented example where the market value principle was used were the negotiations between (Dutch company) Gasunie and its customers in 1983/84 and this has been the basis of Continental European gas pricing since then. ${ }^{4}$ However, the origins of the principle can be traced back to Dutch Minister of Economics J.W. de Pous in the early 1960s. ${ }^{5}$ The market value principle (also known as the netback market value approach) is described as follows: ${ }^{6}$

...the price paid by the gas company to the foreign or domestic gas producer at the border or the beach is negotiated on the basis of the weighted average value of the gas in competition with other fuels adjusted to allow for transportation and storage costs from the beach or the border and any taxes on gas. There are in principle three different average netback market values. These correspond to existing gas users, new gas users (such as greenfield industrial plants) and to existing oil users with no dual firing capability (the market value of the latter being the lowest because of the high capital cost of fuel switching). The beach/border base price that is ultimately negotiated will correspond to a level between the highest and the lowest of the three values, weighted across the different end-user customer categories. The base price is usually indexed to oil product prices (usually heating oil and/or heavy fuel oil) or simply to crude oil (on the implicit assumption that the ratio of crude to product prices will remain broadly constant). This is to ensure that effective prices over the life of the contract remain broadly in line with market values.

This is shown in Chart 1.

\footnotetext{
${ }^{3}$ Gerald B. Greenwald, International Gas Contracts, in Conant 1986, p. 69. 


\section{Chart 1: The Netback Market Value Concept}

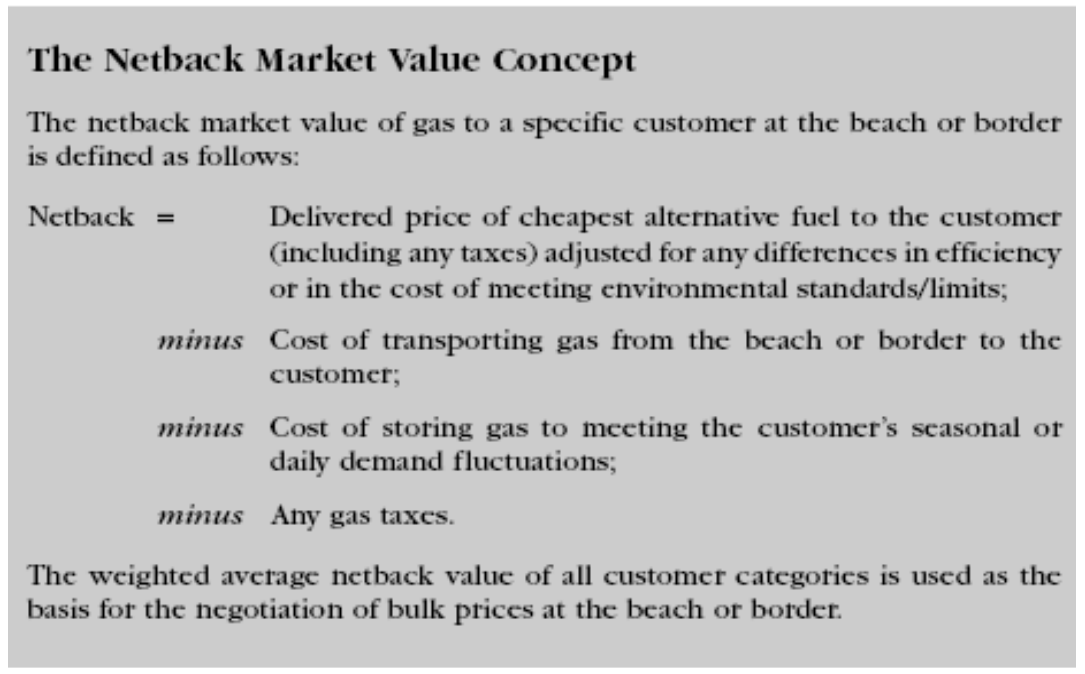

Source: IEA, 1998, p. 32.

\section{ALTERNATIVES TO THE MARKET VALUE PRINCIPLE}

There were two main alternatives to the market value principle in Europe in the 1980s:

A. Parity with crude oil export prices

Parity with crude oil prices was a major issue in the late 1970s and early 1980s, particularly in the Algerian LNG contracts with France and Belgium. ${ }^{7}$ This method of pricing led to gas becoming more expensive than the fuels with which it was competing in end-use markets and losing market share. This was a major factor in the buyers' preference for the market value principle.

B. 'Cost-Plus' pricing

'Cost-Plus' pricing, was the main principle used in the UK by the state-owned British Gas Corporation in its purchases of gas from North Sea producers. Because all gas produced on the UK Continental Shelf was, by law, required to be offered to British Gas, the company was able to determine the cost of production and transportation of gas to the beach, and to offer sellers that price plus a profit margin.

A variant of the market value principle was contained in the 1988 contract between Norwegian sellers and the Dutch power generation company SEP. This contract was intended to make the power generated by imported gas competitive with power generated by coal. Thus the base price was higher than base prices in contracts of that period - reflecting the higher capital cost of building a coal-fired plant compared with a gas-fired plant - and indexed to coal prices in the Netherlands. ${ }^{8}$ This pricing

\footnotetext{
${ }^{7}$ Stern 1984, pp. 72-92.

${ }^{8}$ Stern 1990, p. 32.
} 
methodology did not prove popular and there are no other recorded examples in Europe. It is the only example where the market value principle was applied without using oil products as the benchmark fuel for either the base price or indexation.

\section{CONTINUED RELEVANCE OF OIL PRODUCT LINKAGE IN THE 2000s}

The rationale for oil-linked gas pricing is that natural gas and oil are substitutable in both the short and the longer term. Price formulae were designed to ensure that the customer base continued to burn gas rather than returning to oil products since the majority of customers had switched from oil products to gas and, given a price incentive, retained the ability to switch back. If customers switched back to oil in large numbers, this would not only deprive gas importers of their market, but force them to incur take-or-pay penalties in their contracts with exporters.

To argue that gas prices should continue to be indexed to oil products, it must be possible to demonstrate that:

- in the short term, customers have the capability and incentive to switch existing plant from gas to oil and back again in response to price signals;

- in the long term, customers building new plant (or replacing fuel burning equipment in old plant) will choose to install fuel burning equipment which is principally oil-fired, or equipment which is principally gas-fired but with the option of burning gas or oil products, or a plant with the capacity to switch between the two fuels;

\subsection{The Short Term}

There is very little empirical evidence regarding the ability of existing gas customers to switch from gas to oil products and back again within a few days or weeks. It is not clear whether the data are collected - and in some respects whether they can be collected - on any independently verifiable and comprehensive basis. A major problem is that 'theoretical switching capacity', i.e. estimating the number of customers who could physically switch from gas to oil products if given appropriate commercial incentives, may not be a good approximation to 'real switching capacity' i.e. customers who are actually equipped to burn oil products instead of gas at short notice. In some countries there are environmental constraints which require customers to obtain special permission to emit high levels of sulphur and NOx associated with oil products. ${ }^{10}$

\footnotetext{
${ }^{9}$ There is an important distinction between a plant which has 'dual fuel' capability, i.e. it has a choice of fuel burning equipment which can burn oil and gas (and perhaps also coal), allowing the customer to run either the oil burning or the gas burning equipment. This tends to apply to power stations which have oil, gas and coal burning units on the same site (which is relatively common in Russia and in Japan but less common in Europe). Then there is plant with 'dual-fired' capability where the same equipment can burn either oil or gas with only the burners needing to be changed. Dual-firing tends to be oil and gas, but some power stations can burn oil, gas or coal.

${ }^{10}$ These take the form of permits setting emission limit values (ELVs). These permits will vary depending on the fuel being used. National European regulatory authorities can also impose stricter ELVs (for instance due to air quality problems) which can have an impact on the type and quantity of
} 


\section{Box 1: Evidence of Fuel Switching - The UK during Winter 2005-06}

During the winter of 2005-06, gas prices rose to exceptionally high levels in the UK due to a combination of supply shortfall and lack of storage availability. Some 30 parties obtained temporary permission from the Environment Agency for fuel switching and Grain and Fawley oil-fired power plants were granted derogations from rules capping their generation. The Agency dealt with requests for permanent changes to allow fuel switching from 21 industrial parties and 5 combined cycle gas turbines.

The larger the installation, the more investment and manpower are required to maintain the capability to switch fuels. The Peterhead power station in Scotland which, although designed to burn either gas or fuel oil (gas oil and heavy fuel oil), had not used the latter for more than 10 years. Because of the price differential between gas and oil products, the station burned heavy fuel oil for the entire winter and was forced to overcome significant problems with the provision of equipment and supplies of fuel oil, placing significant strains on the staff at the plant.

The result of gas prices at levels which should have meant that any user able to switch from gas to another fuel certainly would have done, was seen mainly in the choice of power station fuels. While gas used in power generation increased slightly during the winter quarters of 2005-06 compared with 2004-05, use of fuel oil nearly doubled (from $0.7 \mathrm{mt}$ in 2004-05 to $1.27 \mathrm{mt}$ in $2005-06)$ and coal increased by 15 percent ( $2.7 \mathrm{mt}$ oil equivalent). In the industrial sector the data are confusing; total coal use in industry increased by nearly 60 percent while oil use increased by 15 percent suggesting that some gas load did switch fuels, although this only amounted to relatively small quantities of actual demand of less than half a million tons of oil and around $700 \mathrm{GWh}$ of coal. ${ }^{12}$ What these statistics do not adequately reflect is the closure of industrial plants using gas for feedstock, particularly nitrogen and ammonia producers, and changes in overall economic activity for reasons unrelated to energy prices.

In summary, in response to very substantial price and availability incentives, fuel switching amounted to around $1.5 \mathrm{mt}$ of additional oil product demand and around $3.5 \mathrm{mt}$ of additional coal demand, most of which can be assumed to have switched from gas. ${ }^{14}$ While the UK experience cannot be automatically assumed to apply to Continental European countries, some of the same observations seem likely to be relevant.

fuel being used. For larger plants, emission limits are set out in the EU Large Combustion Plant Directive (1988).

${ }^{11}$ However, the Agency noted that fuel switching was not limited to these 29 or 30 parties - many potential fuel switchers have never needed special permission. UK Gas Report, Issue 316, Sept 4, 2006, p. 11

12

12 Data from Energy Trends (Dti), December 2006. It is important to note that these statistics are frequently updated in later editions of the publication; and the final numerical outturn figures may be very different, although it is not likely that this will radically change the picture.

${ }^{13}$ For an account of the impact of high prices by one of these companies see Mackenzie 2006.

${ }^{14}$ Although price incentives were considerable, it cannot be ruled out that greater gas to oil switching could have occurred had gas prices remained in the pounds per therm for a longer period of time. 
The main reasons for the reduction of switching capacity from gas to oil products are practical:

- the need to maintain oil tanks in good condition with an adequate level of stocks, and arrangements for those tanks to be refilled regularly in order to maintain oil burning capacity for more than a few days;

- the need to maintain the pipework between the tanks and the fuel-burning equipment;

- the need to maintain fuel oil-burning equipment in good working order, including the ability to change and clean burners on a regular basis;

- the need to train staff to use oil products, which is significantly more arduous and labour-intensive than the use of gas.

The costs involved in keeping oil-burning equipment and storage in good working order (including the arrangements to ensure continued availability of oil products) and the inconvenience involved in switching, are strong disincentives for many customers to retain this option. Combining these problems with progressive tightening of emission limits on the burning of fossil fuels, it seems likely that the incentive to phase out fuel switching capability, either as a conscious decision or by default, will become increasingly strong.

\subsection{The Longer Term}

In the longer term, justification for the continued linkage of gas to oil prices must rest on the proposition that customers building new plant will choose to build new oilfired plant or plant with the ability to switch to oil products on a significant scale for a protracted period of time. Such a proposition appears increasingly untenable. New gas burning plants - especially CCGT stations - are designed to burn gas only; burning oil in these plants not only causes them to run significantly less efficiently, requiring more fuel to be burned for the same output, but may increase maintenance costs and shorten the life of the turbines. No new oil-fired power plants are being built in Europe. Indeed with the exception of southern Europe where this type of plant is being phased out (and mainly replaced by gas) little oil-fired plant remains in operation in Europe other than for a few hundred hours of peak load. The argument in the residential, commercial and industrial sectors is similar. With the exception of customers with no access to a gas supply (which means that switching is not an option), it is not credible to suggest that any significant proportion of customers will install new fuel-burning equipment in their homes, businesses or industrial plants which will allow them to switch between gas and oil products.

\section{CONTINENTAL EUROPEAN GAS PRICE INDEXATION IN 2004}

Evidence from the sector investigation by DG COMP demonstrates that in 2004, oil products - specifically heavy fuel oil and gasoil - remained the dominant fuels for the indexation of Continental European gas contracts. From an analysis of more than 500 contracts covering more than $400 \mathrm{Bcm}$ of gas supplies to EU countries for calendar year 2004, DG COMP found that two products - light fuel oil and gasoil, and heavy fuel oil - accounted for nearly 75 percent of price indexation (see Chart 2). Gas 
accounted for nearly 10 percent of the index with the rest being a range of other energy products (including crude oil), inflation and non-energy elements.

\section{Chart 2: EU Gas Price Indexation, 2004}
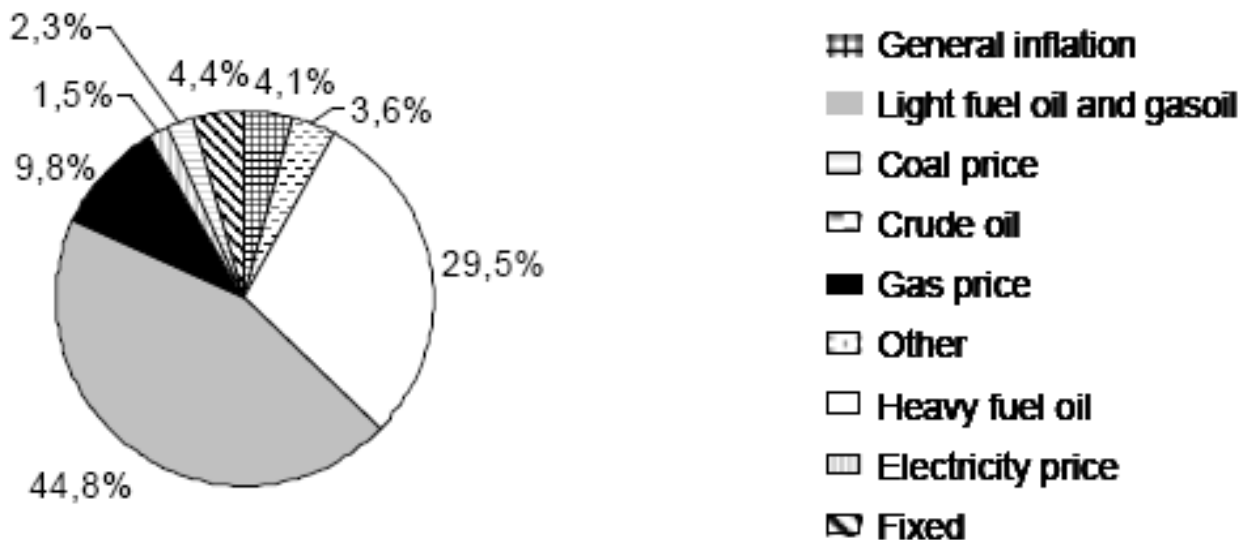

Source: EU Energy Sector Inquiry, 2007, Figure 31, p.102

More detailed data published by DG COMP make clear that indexation is not identical for all producers, or for different regions of the EU. Chart 3 and Table 1 show indexation for a range of internal and external suppliers, from which it is immediately obvious that Dutch, Norwegian and Russian contracts have extremely similar indexation with 35-39 percent heavy fuel oil and 52-55 percent light fuel oil or gasoil. For these exporters, the two products comprise 85-92 percent of the indexation. There is a significant contrast between these contracts and:

- Algerian contracts which were indexed 70 percent to crude oil and 25 percent to heavy and light fuel oil.

- The UK with 37 percent gas indexation, 28 percent inflation and 20 percent heavy and light fuel oil, 15 percent other factors.

- Other EU producers who sell gas within the Union with 30 percent gas and nearly 70 percent heavy and light fuel oil. 
Chart 3: Gas Price Indexation for Different Producers and Exporters
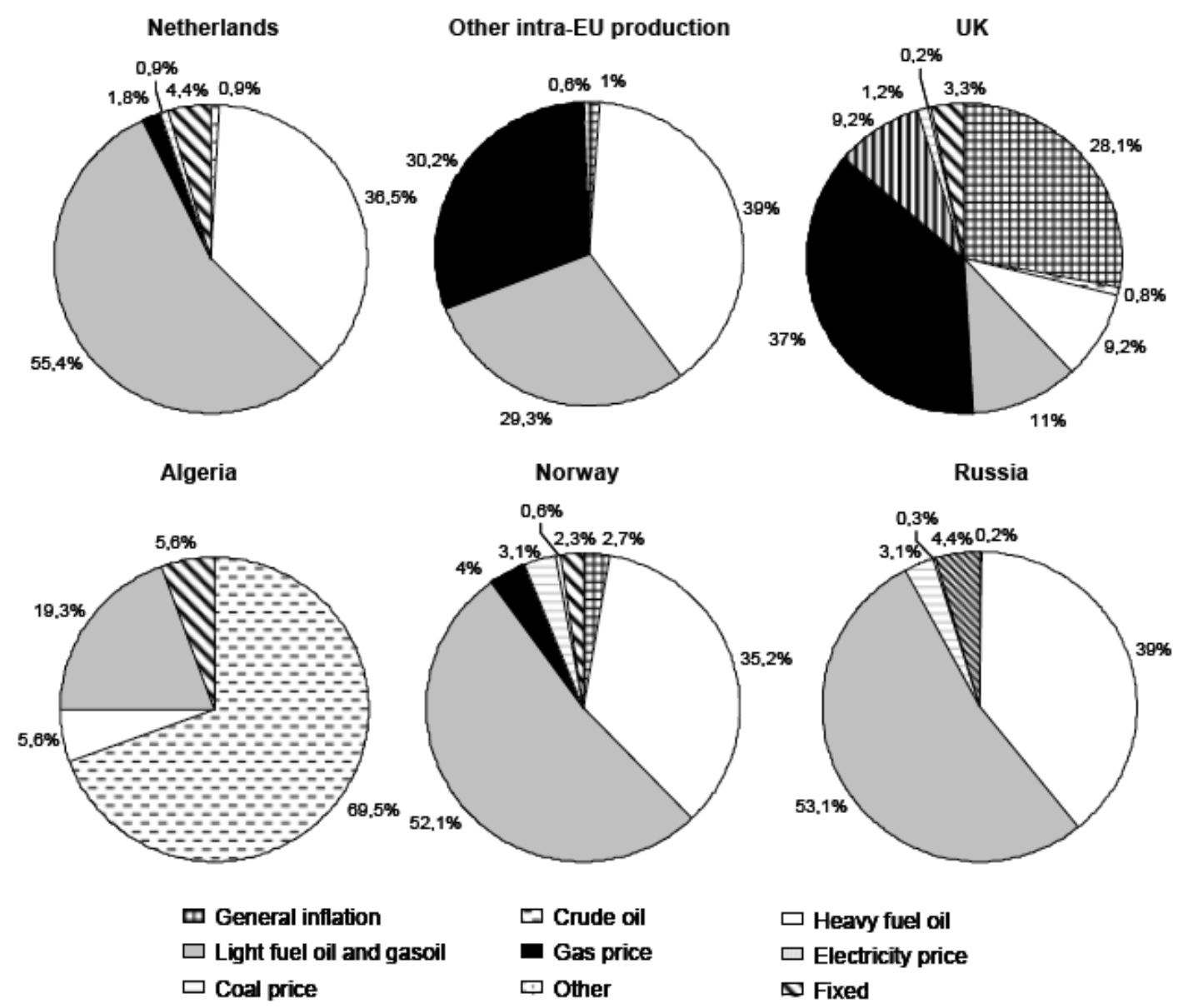

Source: EU Energy Sector Inquiry, 2006, Figure 32, p. 88. 
Table 1: Shares of Crude Oil, Oil Product and Gas in the Gas Price Indexation of Exporting Countries, 2004. Percent

\begin{tabular}{|l|c|c|c|c|c|}
\hline & $\begin{array}{c}\text { Heavy } \\
\text { Fuel Oil }\end{array}$ & $\begin{array}{c}\text { Light } \\
\text { Fuel Oil/ } \\
\text { Gasoil }\end{array}$ & $\begin{array}{c}\text { Crude } \\
\text { Oil }\end{array}$ & TOTAL OIL & Gas Price \\
\hline Netherlands & 36.5 & 55.4 & $0.9^{*}$ & 92.8 & 1.8 \\
\hline Norway & 35.2 & 52.1 & $0.6^{*}$ & 87.9 & 4.0 \\
\hline Russia & 39.0 & 53.1 & 0 & 92.1 & 0.3 \\
\hline Algeria & 5.6 & 19.3 & 69.5 & 94.4 & 0 \\
\hline UK & 9.2 & 11.0 & 0.8 & 21 & 37 \\
\hline $\begin{array}{l}\text { Other intra- } \\
\text { EU }\end{array}$ & 39.0 & 29.3 & 0 & 68.3 & 30.2 \\
\hline
\end{tabular}

*source is very hard to read, these shares may relate to a different product

Source: EU Energy Sector Inquiry, 2006, Figure 32, p.88.

Chart 4 and Table 2 present the same analysis by importing region and show the difference between the UK and Continental Europe. In the UK just over 30 percent of gas was indexed to oil products - and it is likely that this share is rapidly diminishing as old contracts unwind - while the corresponding figure is over 80 percent for western Europe and more than 95 percent for eastern Europe.

Chart 4: Indexation in European Gas Contracts by Purchasing Region 2004.

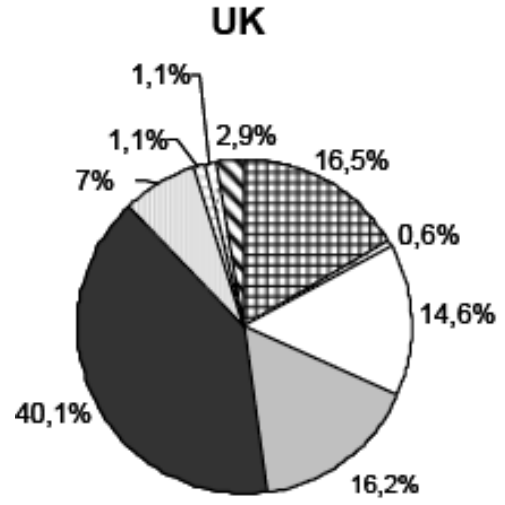

困 General inflation
$\square$ Light fuel oil and gasoil
$\square$ Coal price
Western Europe

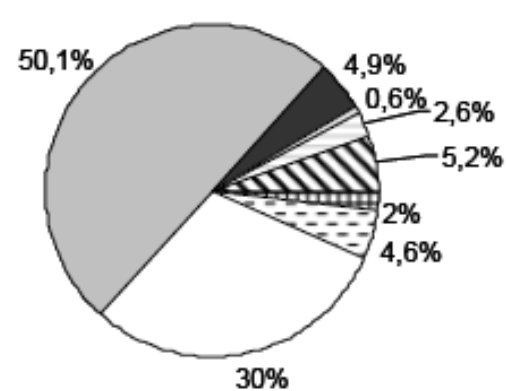

$\boxminus$ Crude oil

- Gas price

Other
Eastern Europe

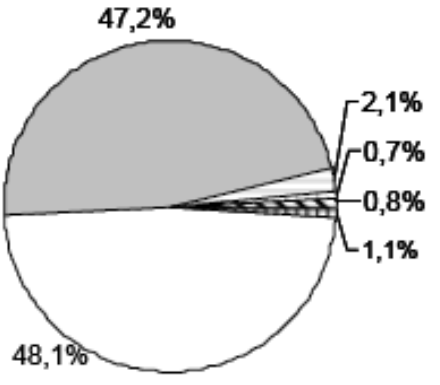

$\square$ Heavy fuel oil
$\square$ Electricity price
$\varangle$ Fixed

Source: EU Energy Sector Inquiry, 2006, Figure 33, p. 89. 
Table 2: Shares of Crude Oil, Oil Product and Gas in Gas Price Indexation of Importing Regions, 2004. Percent

\begin{tabular}{|l|c|c|c|c|c|}
\hline & $\begin{array}{c}\text { Heavy } \\
\text { Fuel Oil }\end{array}$ & $\begin{array}{c}\text { Light } \\
\text { Fuel Oil/ } \\
\text { Gasoil }\end{array}$ & $\begin{array}{c}\text { Crude } \\
\text { Oil }\end{array}$ & TOTAL OIL & Gas Price \\
\hline UK* & 14.6 & 16.2 & $1.1 \%$ & 31.9 & 40.1 \\
\hline $\begin{array}{l}\text { Western } \\
\text { Europe }\end{array}$ & 30.0 & 50.1 & 4.6 & 84.7 & 4.9 \\
\hline $\begin{array}{l}\text { Eastern } \\
\text { Europe }\end{array}$ & 48.1 & 47.2 & $1.1 * *$ & 96.4 & 0 \\
\hline
\end{tabular}

*this indexation reflects contracts for gas produced domestically rather than imported

** source is very hard to read, these shares are possibly for another product

Source: EU Energy Sector Inquiry, 2006, Figure 33, p. 89.

\section{GASOIL AND RESIDUAL FUEL OIL CONSUMPTION TRENDS IN EUROPE}

European energy markets have changed significantly over the past two decades. In most countries, oil and oil products were increasingly forced out of power generation, and then other stationary sectors. Appendix A, Tables 1-10 show a general picture of continuous decline in the consumption of gasoil and residual fuel oil in all stationary sectors of all countries over the past two decades; but over the past decade consumption of gasoil in France and Spain has stabilised, as has consumption of fuel oil in Germany, Belgium and Netherlands (albeit at very low levels). In Spain, gasoil consumption in all sectors (aside from power generation) increased (although not substantially) in the 2000s. In Italy the evidence is inconclusive with increasing oil product demand in some sectors, particularly in $2004 .^{15}$

Tables 3 and 4 show consumption of gasoil and residual fuel oil in six Continental European gas markets which comprised 57.2 percent of the gas demand of Europe 35 in 2005; the corresponding share of these six countries in EU 25 European gas demand was 64.1 percent. $^{16}$ Table 3 shows that the majority of gasoil in non-transport markets is used by household and commercial customers in Germany and France, with Belgium and Spain still significant. Demand in industry is relatively small both

\footnotetext{
${ }^{15}$ Unfortunately 2004 is the latest year for which comprehensive (i.e. country by country, product by product) data of oil product demand are available; 2005 data will not be available until July/August 2007.

${ }^{16}$ Data from IEA 2006. Europe 35 comprises all EU member states and accession countries including the Balkans and Turkey, stopping at the borders of the Ukraine and Belarus. Adding the demand of the UK to these 6 countries would bring these figures up to 83 percent of EU 25 and 74 percent of Europe 35 demand. For details see: Honoré 2006, Table 2, p. 21.
} 
in terms of total gasoil demand and in relation to total fuel use in the relevant sectors of these countries. Table 4 shows that two-thirds of residual fuel oil in these countries is used in Italian and Spanish power stations. There is barely any remaining fuel oil demand in the household and commercial sectors, and significant industrial use only in Germany and Italy.

Table 3: Consumption of Gas/Diesel Oil in Stationary Sectors, 2004. Thousand Tons

\begin{tabular}{|l|c|c|c|c|c|}
\hline & INDUSTRY & HOUSEHOLDS & COMMERCIAL & POWER & Total \\
\hline Germany & 2833 & 16193 & 6112 & 444 & 25582 \\
\hline France & 2985 & 8050 & 4290 & 79 & 15404 \\
\hline Netherlands & 181 & 24 & 193 & 9 & 407 \\
\hline Belgium & 292 & 3410 & 1137 & 5 & 4844 \\
\hline Italy & 1198 & 3527 & 378 & 215 & 5318 \\
\hline Spain & 1505 & 2557 & 1604 & 0 & 5666 \\
\hline TOTAL & 8994 & 33761 & 13714 & 752 & 57221 \\
\hline
\end{tabular}

Source: IEA Oil Data

Table 4: Consumption of Residual Fuel Oil, 2004. Thousand Tons

\begin{tabular}{|l|c|c|c|c|c|}
\hline & INDUSTRY & HOUSEHOLDS & COMMERCIAL & POWER & Total \\
\hline Germany & 3749 & 0 & 0 & 1680 & 5429 \\
\hline France & 1730 & 267 & 98 & 954 & 3049 \\
\hline Netherlands & 19 & 0 & 21 & 17 & 57 \\
\hline Belgium & 696 & 0 & 17 & 447 & 1160 \\
\hline Italy & 3475 & 259 & 0 & 11327 & 15061 \\
\hline Spain & 1085 & 63 & 257 & 4891 & 6296 \\
\hline TOTAL & 10754 & 589 & 393 & 19316 & 31052 \\
\hline
\end{tabular}

Source: IEA Oil Data

\subsection{Shares of Gasoil and Fuel Oil in Stationary Energy Demand}

Tables 5-7 show the share of gas and its two main competing oil products - gasoil and residual fuel oil - in the energy mix of the four main stationary energy markets in 2004. The following features stand out from these tables: gasoil has been eliminated 
from power markets in all countries; in the industrial sector, the fuel's share is only significant in France ( 8 percent) with Germany being the next highest at just over 5 percent (see Table 5). But household consumption of gasoil remains significant in all countries other than the Netherlands, ranging from 12 percent of residential energy demand in Italy to a surprising 34 percent in Belgium. In the commercial sector, the share of gasoil is higher than residential in all countries, other than Belgium and Italy, and is significant in all countries (other than Netherlands and Italy) ranging from 19 to 28 percent of fuel use.

Table 5: Share of Gas Oil in Total Energy Consumption of Stationary Sectors, 2004. Per Cent

\begin{tabular}{|l|c|c|c|c|c|}
\hline & INDUSTRY & HOUSEHOLDS & COMMERCIAL & POWER & Total \\
\hline Germany & 5.3 & 21.2 & 25.1 & 0.6 & 11.6 \\
\hline France & 8.0 & 16.6 & 27.6 & 0.2 & 10.2 \\
\hline Netherlands & 1.3 & 0.2 & 2.3 & 0.08 & 0.9 \\
\hline Belgium & 2.6 & 33.8 & 27.9 & 0.06 & 14.6 \\
\hline Italy & 3.1 & 11.7 & 3.0 & 0.7 & 4.8 \\
\hline Spain & 5.1 & 17.4 & 20.6 & 0 & 7.5 \\
\hline TOTAL & 4.9 & 17.7 & 18.9 & 0.4 & 9.0 \\
\hline
\end{tabular}

IEA Oil Data

Table 6. Share of Residual Fuel Oil in Total Energy Consumption of Stationary Sectors, 2004. Percent

\begin{tabular}{|l|c|c|c|c|c|}
\hline & INDUSTRY & HOUSEHOLDS & COMMERCIAL & POWER & Total \\
\hline Germany & 7.1 & 0 & 0 & 2.5 & 2.4 \\
\hline France & 4.7 & 0.5 & 0.6 & 1.2 & 2.0 \\
\hline Netherlands & 0.1 & 0 & 0.2 & 0.1 & 0.1 \\
\hline Belgium & 6.3 & 0 & 0.4 & 5.7 & 3.5 \\
\hline Italy & 8.9 & 0.9 & 0 & 38.1 & 13.5 \\
\hline Spain & 3.7 & 0.4 & 3.3 & 20.5 & 8.3 \\
\hline TOTAL & 5.9 & 0.3 & 0.5 & 10.2 & 4.9 \\
\hline
\end{tabular}

IEA Oil Data

Residual fuel oil has largely been driven out of all sectors other than power with the largest remaining shares being between 7 and 9 percent in the German and Italian industrial sectors (see Table 6). In the power sector, the only significant remaining shares are in Spain and Italy and these are likely to reduce very substantially as gasfired (CCGT) generation is introduced for economic and environmental reasons. 
Table 7: Share of Gas in Total Energy Consumption of Stationary Sectors, 2004. Percent

\begin{tabular}{|l|c|c|c|c|c|}
\hline & INDUSTRY & HOUSEHOLDS & COMMERCIAL & POWER & Total \\
\hline Germany & 35.9 & 37.2 & 30.9 & 19.2 & 30.7 \\
\hline France & 38.7 & 36.1 &.. & 3.2 &.. \\
\hline Netherlands & 44.4 & 75.7 & 53.3 & 67.6 & 59.7 \\
\hline Belgium & 39.8 & 37.3 & 43.4 & 30.1 & 37.2 \\
\hline Italy & 43.3 & 56.7 & 48.3 & 46.6 & 48.4 \\
\hline Spain & 41.7 & 20.6 & 4.1 & 20.0 & 27.0 \\
\hline TOTAL & 39.8 & 40.8 &.. & 22.8 &.. \\
\hline
\end{tabular}

Source: IEA Oil Data

Gas has a very substantial share of all stationary sectors in all countries with the exception of power in France (because of the preponderance of nuclear power) and the commercial sector in Spain (Table 7). The share of power is relatively low at 20 percent in Germany (because of coal) and in Spain (but this will rise as new CCGTs are commissioned); likewise the share of gas in the Spanish household sector will rise as the network expands. Elsewhere gas has a 30-45 percent share of stationary fuel demand with exceptionally high penetration in the Dutch household sector.

\subsection{Evidence of Gas to Oil Product Switching}

Tables 3-6 broadly show that gasoil demand in the six countries is concentrated in the household and commercial sectors, with some industrial load; while residual fuel oil demand is concentrated in the power sector with some industrial load. Because of the technical and logistical difficulties involved in switching described above, it is less likely that household and commercial customers will have the option to switch from gas to oil products; the majority of remaining switchable capacity in these countries is most likely to be in the industrial and power sectors involving potentially significant quantities of residual fuel oil and limited quantities of gasoil. ${ }^{17}$

Appendix B Tables 1-10 show the change in demand for these products in different sectors in the 2000s. These data can be used as a guide to switching behaviour - but only a rough guide because the data in these tables are not temperature-corrected so it is impossible to know whether increased demand is due to a weather-related response or switching from gas. It is more likely that increases in demand in the household and commercial sectors were due to weather-related events, and increases in the industrial sectors were due to switching from gas, but this cannot be conclusively demonstrated. Industrial gas demand is also likely to be affected by GDP growth and levels of

\footnotetext{
${ }^{17}$ There is the possibility for household and commercial customers to switch from gas to electricity for heating on a temporary (or permanent) basis but no way to measure this.
} 
economic activity in individual industrial sectors. Tentative conclusions from these tables on switching from gas to oil products during the period 1999-2004 are as follows: ${ }^{18}$

- Appendix B, Tables 1-5 relating to gasoil: the years 2002-04 saw some significant demand increases in Spain and Italy in the household sector; Spain and France (and to a lesser extent Germany) in the industrial sector, and Spain in the commercial sector. Similar increases were visible in the Belgian industrial sector in 2000-01, the household sector in 2002-03, and the commercial sector in 2001-03.

- Appendix B, Tables 6-10 relating to residual fuel oil: the period 1999-2001 saw some significant increases in industrial demand in Germany, similarly in 2001-03 in Italy. In the power sector, there were significant increases in demand in Germany and Belgium in 2002-04, Belgium in 2000-01, Italy in 2001-02, and Spain 2001-02 and 2003-04.

If all of these increases did actually represent switching from gas to oil products (as opposed to temperature-related demand increases), then switching has generally been in the range of 100,000-400,000 tons of an oil product in an individual country during an individual year. Larger volume switching has only been seen:

- for residual fuel oil in the Spanish power sector in 2001-02 and 2003-04, and the German industrial sector in 1999-2000.

- for gasoil in the German commercial sector in 2001 and French and German households in 2001.

For gasoil in all countries in all years, the maximum volume of increase was in Germany and France in 2001 with over $6 \mathrm{mt}$ combined (Table 1 Appendix B) of which $2.7 \mathrm{mt}$ was accounted for by the German household sector alone. For fuel oil the most significant increase, nearly $2.5 \mathrm{mt}$, occurred in 2002 in Italy and Spain (of which nearly $2 \mathrm{mt}$ was in the power sector, Tables 6 and 10 Appendix B). Outside the household and commercial sectors (where cold weather is a more likely explanation for increased demand than switching) the maximum annual increase in a single country was $1.7 \mathrm{mt}$ of residual fuel oil in the German industrial sector in 2000 .

The main conclusion of this overview of oil product statistics is that there is little evidence of significant gas to oil product switching in most countries, with the possible exception of Spain, and the Italian power sector. Not only does switching appear to be limited, but it would also appear to be declining in all countries, which is what would be expected from anecdotal evidence of industrial and power sector usage of oil products. This does not mean that the original rationale for oil product linkage has become completely irrelevant. But with switchable capacity in North West Europe seemingly reduced to a few million tons of gasoil and residual fuel oil, the capacity will be quickly exhausted, after which any price linkage with oil will break down. ${ }^{1}$

\footnotetext{
${ }^{18}$ It is a pity that 2005 data are not yet available (see note 15) as very cold weather in a number of Continental European countries should have created very strong switching incentives.

19 i.e. once all customers who can switch to oil products have switched, there is no longer any linkage between these prices.
} 
It is also important for our purposes that in all countries transportation is a more important market for gasoil than all other stationary sectors combined (compare Tables 3 and 8). In Spain, Italy and France gasoil demand for transportation is 2-4 times greater than combined demand in all stationary sectors. This suggests that certainly for gasoil, demand dynamics in the transportation sector will be as important, and arguably a more important determinant of price than demand in the stationary sectors. For fuel oil where the transport market is only for marine bunkers, these volumes are dominant only in Netherlands and Belgium - because of the importance of Rotterdam and Antwerp as trading locations which accounted for more than $20 \mathrm{mt}$ in 2004. A comparison of Tables 4 and 8 shows that stationary fuel oil consumption in Germany and France remains significantly greater than for bunker fuels. In 2004, total fuel oil demand for bunkers in the six countries exceeded the total for other end uses combined and this trend may accelerate as fuel oil is phased out of power generation in Spain and Italy.

Table 8: Gas/Diesel Oil and Residual Fuel Oil Demand in Transportation and Petrochemicals, 2004. Thousand Tons

\begin{tabular}{|l|c|c|c|c|}
\hline & \multicolumn{2}{|c|}{ Transport } & \multicolumn{2}{c|}{ Petrochemicals } \\
\hline & Gas/Diesel & $\begin{array}{c}\text { Fuel Oil in } \\
\text { Marine Bunkers* }\end{array}$ & Gas/Diesel & Fuel Oil \\
\hline Germany & 27594 & 2275 & 181 & 862 \\
\hline France & 30287 & 2780 & 252 & - \\
\hline Netherlands & 6480 & 13229 & - & - \\
\hline Belgium & 6458 & 7541 & - & 367 \\
\hline Italy & 22472 & 2711 & 302 & - \\
\hline Spain & 24231 & 6483 & - & 1229 \\
\hline TOTAL & 117522 & 35019 & 735 & - \\
\hline
\end{tabular}

*aside from bunkers 154,000 tons of fuel oil was used for transport in Spain and 2000 tons in Belgium

Source: IEA Oil Data

\section{GASOIL AND RESIDUAL FUEL OIL PRICE TRANSPARENCY AND MARKET LIQUIDITY}

In addition to switching, there was another important reason for choosing oil indexation in long-term gas contracts: crude oil and oil products were part of a regional (and increasingly a global) market with prices set (or at least strongly influenced) by OPEC, quoted at a number of locations in Europe in a range of widely accepted industry publications (Platts, Argus, and so on). The size and liquidity of these markets meant that they could not be manipulated by any single player or group of players, however large, and certainly not by gas exporters or importers. 
Chart 5: Open Interest for ICE Gasoil Futures, 1999-2006

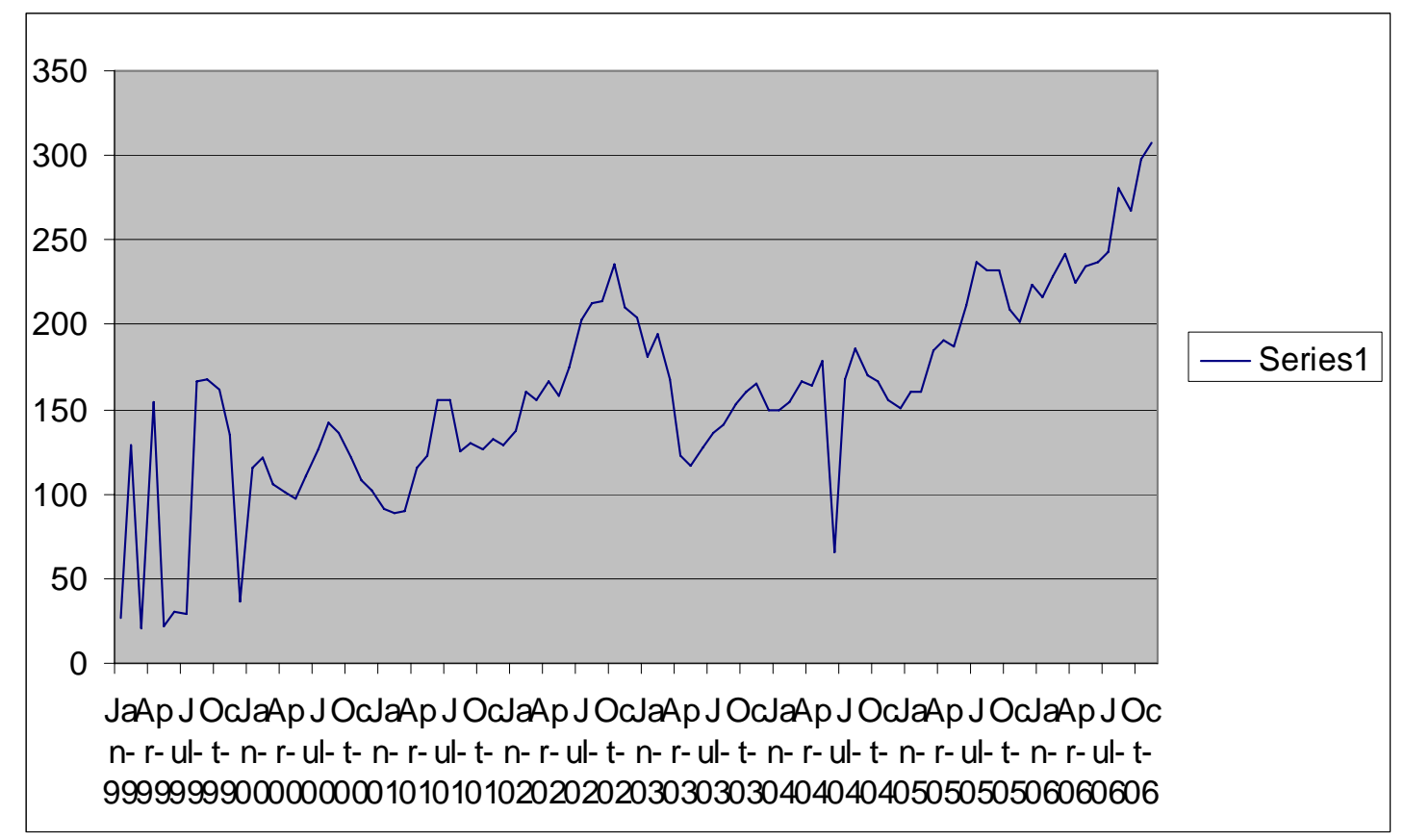

Source: Platts

As far as the gasoil market is concerned, that conclusion remains robust. Chart 5 shows open interest for gasoil futures from the ICE quoted weekly by Platts. ${ }^{20}$ Despite significant volatility in 1999-2000 and one sharp dip in 2004, liquidity is increasing and there is no problem with data transparency and availability. However, the case of fuel oil is very different. There is no futures market with exchange-quoted prices in (any grade of) fuel oil, only an over-the-counter (OTC) market which (anecdotally) trades 10-15 cargoes per month in North West Europe. It is therefore difficult to know the liquidity of the fuel oil market and the number of trades from which prices are calculated. We have not been able to locate any publicly quoted data for different grades of fuel oil. ${ }^{21}$ Anecdotally, the market for high sulphur fuel oil has reduced considerably (which would be expected in the light of tightening emission limits) and currently the highest demand is for product with a 1 percent sulphur content (either used directly or for blending). The German National Statistical Office (Statistisches Bundesamt) publishes data for heavy fuel oil, but these are only available on subscription. ${ }^{22}$ There is a question as to the robustness and relevance of the indexation provided by these quotations. The Statistical Office asks companies to provide price information once per month and the number of quotations from which they compile the index is not clear. Aside from the German statistics, fuel oil price quotations in

\footnotetext{
${ }^{20}$ The Intercontinental Exchange (ICE) was formerly known as the International Petroleum Exchange (IPE).

${ }^{21}$ By 'publicly' we mean data that can be accessed without subscribing to information services such as Argus which quotes prices for fuel oil with 1 percent and 3.5 percent sulphur content. Argus European Products, Methodology and Specifications Guide, January 2007.

22

The subscription fee is relatively low and the data are available from a number of information providers.
} 
North West Europe relate to bunker fuels for marine transportation and therefore have no relationship with markets in which gas competes.

Given that between 30 and 50 percent of European gas prices are indexed to heavy fuel oil prices, several problems arise, i.e.:

- There is no easily available statistical source which quotes prices for different fuel oil products in different European countries and regions;

- there is no way of knowing the extent of liquidity in the markets for these products;

- a likelihood exists that prices may be substantially influenced by the bunker market.

\section{ALTERNATIVES TO OIL PRODUCT INDEXATION: TOWARDS GAS INDEXED PRICES?}

As noted at the beginning of this paper it was expected that, with the introduction of liberalised and competitive markets, Continental European countries would move to gas-indexed prices created by trading at a single hub (or multiple hubs) and quoted on a single exchange or multiple exchanges. The best known examples are Henry Hub prices quoted on the New York Mercantile Exchange (NYMEX) which sets prices throughout North America, and the National Balancing Point (NBP) quoted on the Intercontinental Exchange (ICE) and other reporting services in the UK.

Because of the slow progress towards liberalisation and competition no such developments have taken place in Continental Europe. Nevertheless, hubs have evolved in many countries as shown in Chart 6.

\section{Chart 6: European Gas Market Hubs}

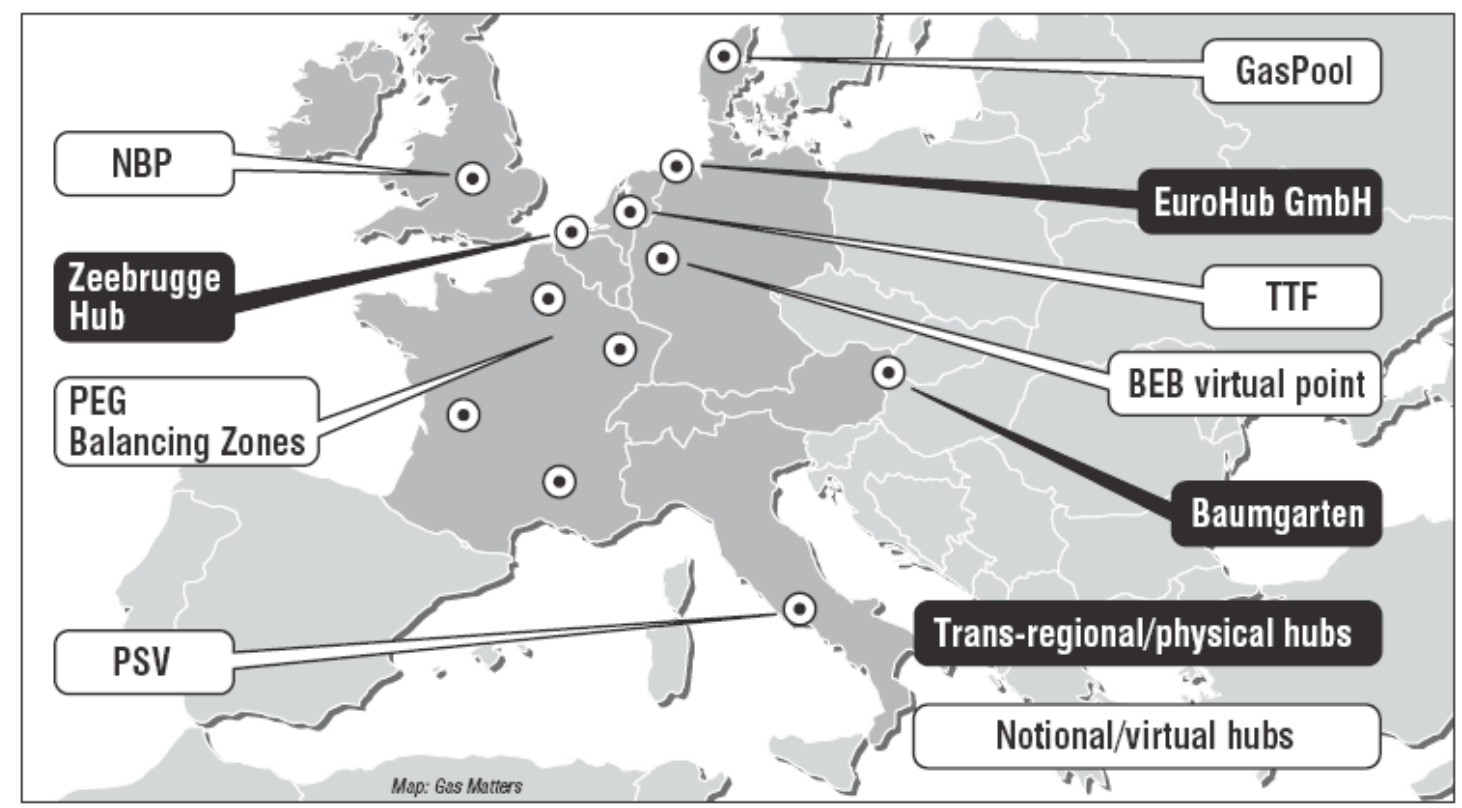

Source: Gas Matters, May 2005, p. 9.

The problem with Continental European hubs is threefold: lack of trading volume, insufficient liquidity, and risk of price manipulation by dominant national players. 
Volume is a simple measure of gas traded; liquidity is generally measured by the 'churn rate' which is defined as the ratio between the total volume of trades and the physical volume of gas consumed in the area served by the hub. ${ }^{23}$ During the period 2004-2006, the NBP traded 500-800 million therms of gas per day with a churn rate at the NBP of 8-14 probably averaging 10, which is considered an acceptably liquid market. ${ }^{24}$ In 2006, 62 participants recorded transactions using the ICE natural gas futures contract, with funds accounting for 6 percent and banks for 24 percent of the total. ${ }^{25}$ For comparison, the churn rate at Henry Hub over the same period was around 30 .

\section{Chart 7: NBP Throughput, Trades and Churn, October 2004-October 2006}

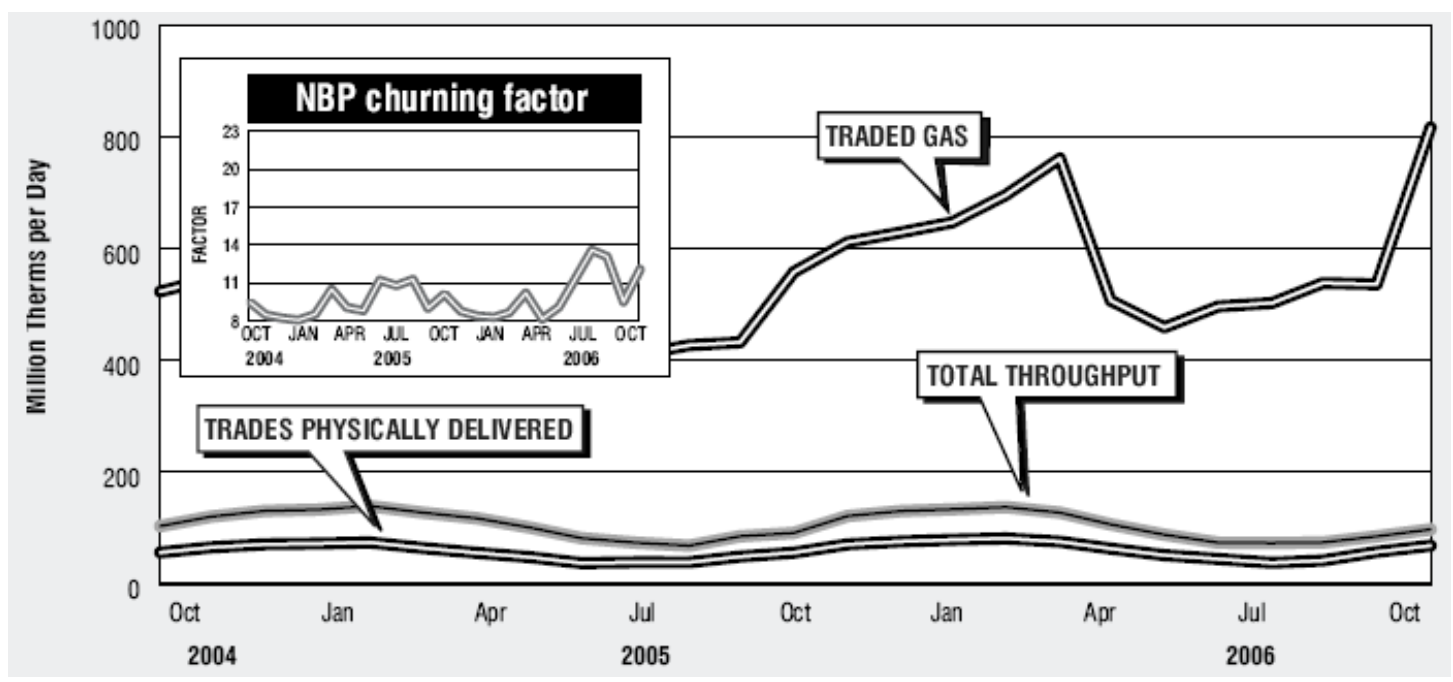

Source: Gas Matters, November 2006, p. 47.

However, the extent of liquidity at the NBP should not be overestimated, particularly beyond a few months. While it is a gross overstatement to claim that the NBP is 'just a balancing market for the day ahead', the vast bulk of the liquidity is in the dayahead and month-ahead contract; significant volumes are traded for months up to a year-ahead. ${ }^{26}$ Gas is traded for up to 10 years ahead between a small number of very large players (especially banks). The limitations on credit which followed the departure of many American players from the market, in the wake of the collapse of Enron, have adversely affected longer-term confidence in (and hence liquidity of), the forward curve. The question which will be raised below as to whether it would be appropriate for the NBP to serve as the price setting hub for the whole of Europe (as Henry Hub does for the whole of North America), must to some extent be judged by

\footnotetext{
${ }^{23}$ This is the definition from EU Energy Sector Inquiry 2007, para 70, note 52. It is not the only possible definition of 'churn' and it is often difficult to find an exact definition in sources that quote such figures.

${ }^{24}$ For details of the different marketplaces, contracts and prices in the UK see Wright 2006, Chapters 3 and 4.

${ }^{25}$ Report to UK Natural Gas Participants, ICE Futures, December 18, 2006.

${ }^{26}$ For details of the standard futures contracts see Wright 2006, pp. 66-7.
} 
whether it would be appropriate for prices in North West Europe to be set by supply/demand conditions in Britain.

Chart 8 shows average daily volumes traded at the major continental European hubs. Relating this to the volumes shown in Chart 7, over a similar period, NBP traded 15000-25000 GWh/day - more than ten times the volume at Zeebrugge, the largest Continental European hub in terms of traded volumes.

\section{Chart 8: Average Daily Volumes Traded on Continental European Gas Hubs, October 2003-06}

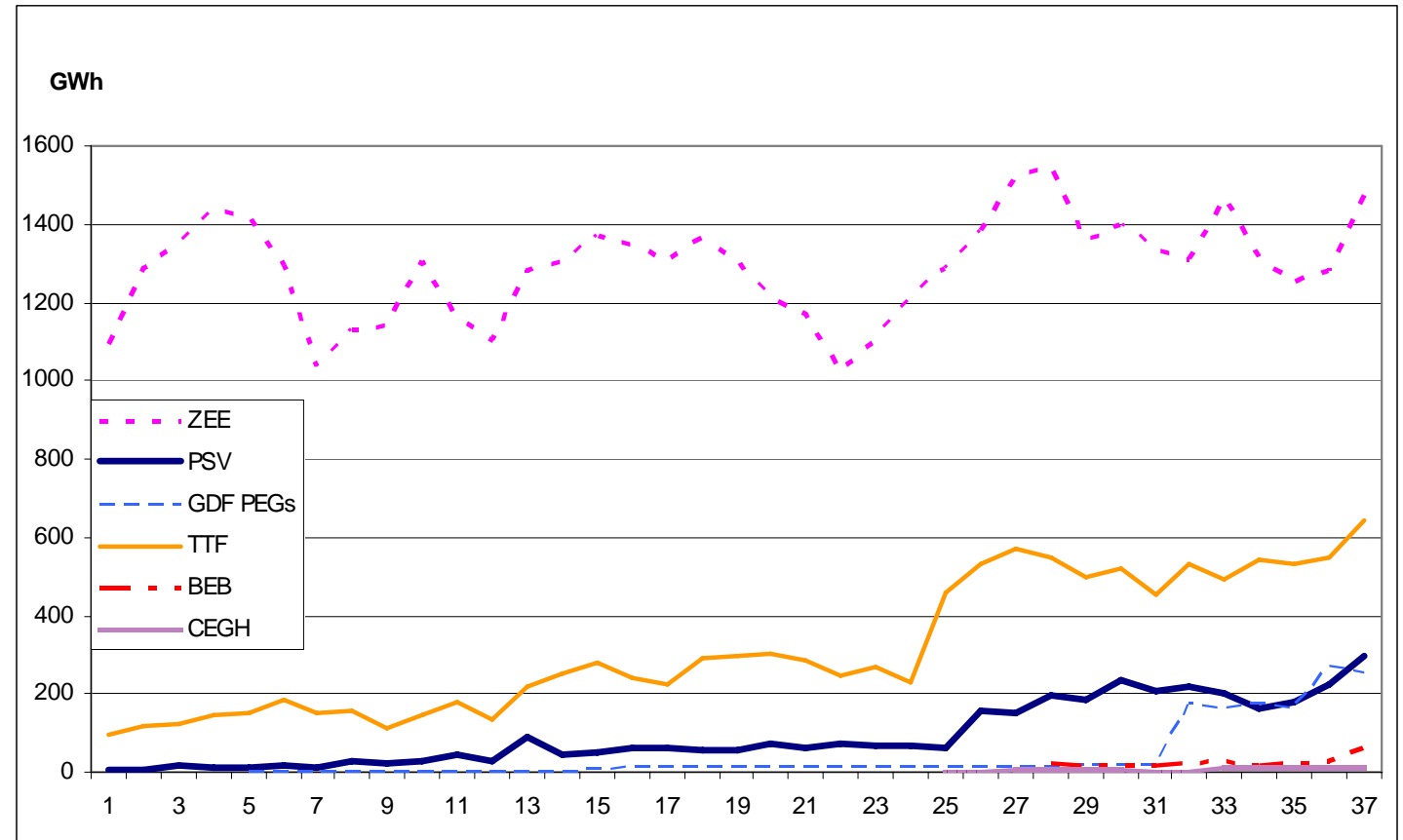

Source: Heren Energy

Similarly, Chart 9 shows churn rates at Continental European hubs in comparison with the NBP. The highest Continental European churn rate is 4 at Zeebrugge Hubin Belgium followed by 3 at the Dutch Tittle Transfer Facility (TTF) with the rest much smaller. Charts 8 and 9 somewhat understate the rapidly increasing importance of TTF where - in contrast to the other Continental European hubs - by the beginning of 2007, gas was trading several years ahead and liquidity was growing and the churn rate has been quoted as high as 7 . Chart 9 shows the churn for a single month which is somewhat misleading since the churn at some of these hubs - particularly in the PEG zones - have been as high as 3 . Nevertheless the general proposition that they are nowhere near the liquidity that would be needed to create a European gas-indexed price is valid. The hub run by the German company BEB, the Central European Gas $\mathrm{Hub}(\mathrm{CEGH})$ at Baumgarten in Austria, and the Punto de Scambio Virtuale (PSV) in Italy which appear in Chart 8 but not Chart 9 are in their infancy and are almost exclusively used for physical balancing so would not be expected to have high churn rates. While a central European hub (or hubs) could emerge solely for purposes of physical balancing, the existence of low as well as high calorific value gas networks 
in North West Europe is a serious complication and reduces potential liquidity. ${ }^{27}$ This would be a somewhat different model to either:

- Henry Hub in the USA where a confluence of pipelines and storage facilities enabled a hub-based traded market to take off;

- The NBP which is a virtual hub, representing gas delivered into the British high pressure network, created by regulatory authorities for the purpose of launching a traded market.

\section{Chart 9: Churn Rate at European Gas Hubs, October 2006}

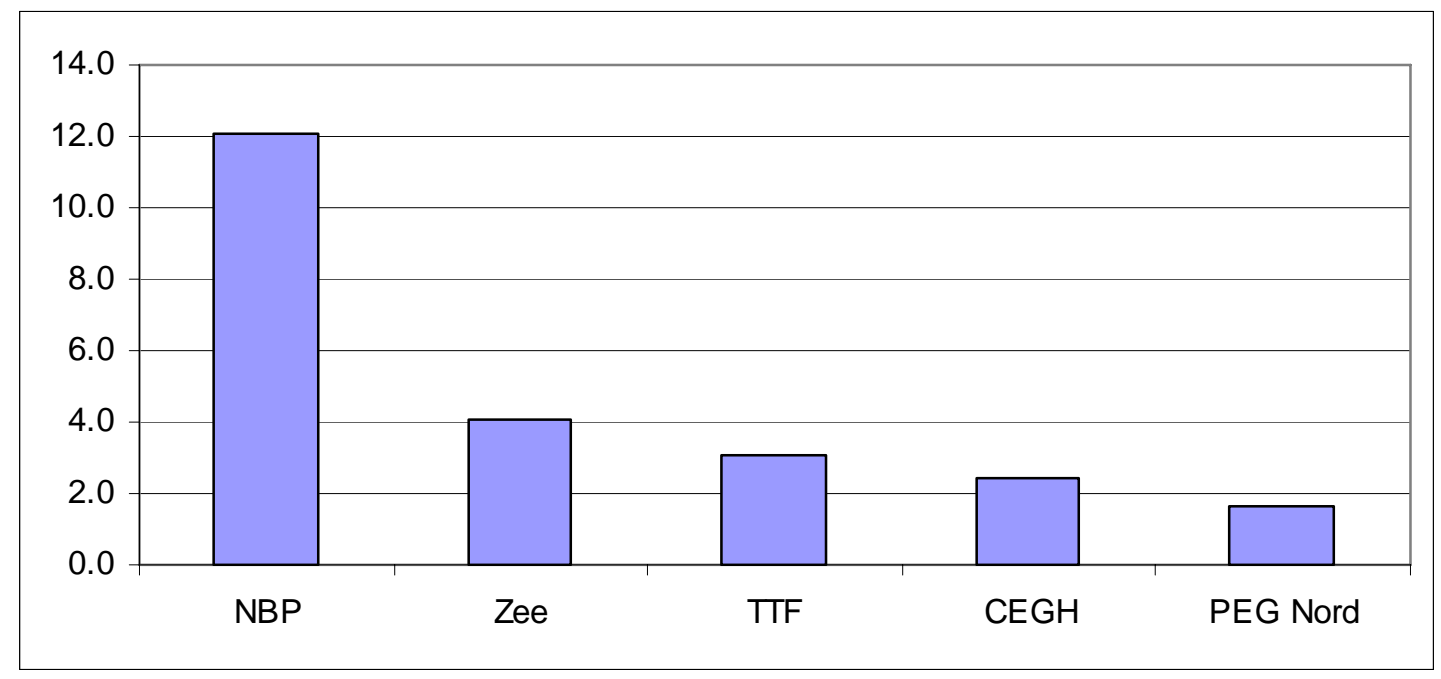

Source: Heren Energy.

While the opening of markets to competition down to the residential level by July 2007 should, in theory, put pressure on even the largest incumbent companies to make a choice between offering discounted prices and losing market share, past history suggests reason to doubt this will happen on a large enough scale to create significant gas-to-gas competition. Should this judgement prove overly pessimistic, Continental European gas utilities would need their long-term gas contracts to reflect a much greater degree of gas-indexed prices than is currently the case (less than 5 percent according to the information published by DG COMP, see Tables 1 and 2). By contrast, the creation of balancing markets and therefore the need to trade on a daily basis is the most compelling reason for expecting increased demand for hub-based services over the next $1-2$ years.

It is unlikely that a uniform indexation will be appropriate for all Continental European - or even all North West European - markets with national or regional solutions emerging depending on local conditions. What follows are some of the more obvious suggestions and the issues which they raise:

\footnotetext{
${ }^{27}$ Low calorific gas is delivered from the Groningen field through local networks to the Netherlands and to North West European countries. It contains 14 percent nitrogen and without treatment and blending facilities, it cannot be mixed with high calorific value gas which is distributed in separate networks.
} 
- North West Europe could operate a gas index based on a combination of the $\mathrm{NBP} / \mathrm{TTF} /$ Zeebrugge hubs where prices are converging as physical incfrastructure connecting them increases. The most likely single candidate hub would be the NBP, both because it is most developed and because other hubs are more likely to be suspected of being controlled by incumbents. But the main issue is whether NBP prices reflect British, rather than more general European, market conditions and if so whether it can become a more regional price index.

- The extent to which the geographical location of the hub is important is open to question. With easy and reasonably priced access to networks, gas can be traded between locations using transportation 'basis' differentials as happens in North America. But given the difficulty and cost of obtaining access to networks and access to flexible gas - particularly storage - in much of Continental North West Europe, this remains a problem. ${ }^{28}$ Until these problems - particularly access to storage and other sources of flexible gas are resolved, trading is unlikely to work well irrespective of the location of the hub; once they are resolved it is not clear whether the location - as opposed to the liquidity - of the hub is a critical factor.

- A country-by-country gas index, based at the hubs in Chart 6 is an attractive proposition but is unlikely to be able to develop sufficient liquidity, and will be subject to suspicion of manipulation by dominant players. But Spain's significant dependence on LNG, and hence exposure to Atlantic (and to some extent Pacific) Basin pricing, means that the current combination of Henry Hub, NBP and Brent crude prices may be a more appropriate index for that country than one derived from a gas hub in North West Europe.

- Power generators buying gas for new developments could require an index based on some mix of coal, electricity and carbon prices.

It is not the purpose of this paper to investigate which of these outcomes is likely or more likely than others. Only to point out that because the future of gas pricing looks much more complicated than the past, a continuation of the current oil product-linked model is becoming increasingly commercially inappropriate.

\section{ARGUMENTS FOR AND AGAINST OIL PRODUCT-LINKED PRICING}

The DG COMP sector investigation identified three groups of stakeholder views on this subject: ${ }^{29}$

- Incumbents and producers who are strongly in favour of retaining it;

- Regulators, entrants and traders who consider the link to be a symptom of lack of competition rather than a problem to be addressed in isolation;

\footnotetext{
${ }^{28}$ For details see EU Energy Sector Inquiry 2007; EU Benchmarking Report 2007.

${ }^{29}$ EU Energy Sector Inquiry 2007, para 693, p. 219.
} 
- Entrants, customers and government agencies who are strongly against the link.

\subsection{Incumbent Perspectives: issues of market power}

The traditional arguments in favour of oil linkage are well known: transparency, stability, reliability, necessity to enable investment and avoidance of price volatility. But the most persuasive arguments as to why indexation to oil products will (rather than should) continue are those relating to market power. Continental European incumbent utility companies, and in particular many of the producers and exporters who supply them, wish to retain this contractual mechanism and their market power will allow them to do so. This argument goes as follows:

- Relatively few countries export gas, and still fewer export gas to Europe. Aside from domestic production, European gas supplies are dominated by deliveries from the Netherlands, Norway, Algeria and Russia.

- Over the next decade, substantial additional gas supplies will come in the form of LNG from Nigeria, Qatar and Egypt. ${ }^{31}$ State-owned or state-controlled companies in these countries believe it is in their interest to restrict competition, and prevent a multiplicity of companies competing to export gas to different markets.

- Furthermore, at the oil price levels of the post-2003 period, these governments and their state shareholders have very strong incentives to maintain oil price linkage in their contracts, and are entitled to extract the maximum available rent from their resources.

Some extend the defence of the market power argument with the proposition that, since it is likely that the current small number of producers and exporters will dominate the European gas market in the future, it would be better to retain a contractual mechanism which cannot be controlled by those suppliers, rather than run the risk that a handful of state-owned/controlled companies would be able to dominate any price index that might emerge in Europe. An extreme form of this argument is that the likelihood of Gazprom domination of the European gas market is so great, that it would be preferable to rely on a price mechanism controlled by OPEC countries which exercise little influence on gas markets, rather than run the risk of handing over control of the price mechanism to a small group of exporting countries dominated by Russia. This argument can be further extended to a discussion of the possible creation of a 'Gas OPEC' with market power to control the price of gas charged to Europe. ${ }^{32}$

\footnotetext{
${ }^{30}$ EU Energy Sector Inquiry 2007, para 694, p. 219.

31 The emphasis here should be on the word 'substantial'; some additional supplies will be received from Libya, Trinidad, Equatorial Guinea and a number of other LNG suppliers. Some commentators, but not this author (Stern 2006), believe that substantial pipeline supplies from Caspian and Middle East countries will also be available to Europe within a decade.

${ }^{32}$ Hallouche 2006, Stern 2006, Stern 2007.
} 
It is uncertain whether the determination of exporters to continue oil-price linkage is universally applicable. All major suppliers to the Continental European gas market including Gazprom - also operate in the British market where the NBP is the dominant price-setting mechanism. New LNG entrants to the UK market - the $\mathrm{BP} /$ Sonatrach venture at the Isle of Grain, the Qatar Petroleum/ExxonMobil joint venture at South Hook and the Dragon joint venture led by BG - all sell (or will sell) their gas in the UK at NBP prices (and in the US market at Henry Hub prices). Some major pipeline exporters - in discussion at least - would be, in principle, willing to sell at gas-indexed prices as long as they could satisfy themselves that price manipulation by dominant market players (sellers or buyers) could be avoided. But there is universal agreement with the proposition that the current major exporters and incumbent importers are 'comfortable' with traditional oil price linkage and are certainly not in a hurry to see it disappear.

\subsection{Regulatory Perspectives}

Those who continue to defend oil product-linked prices on the basis of market power arguments run an increasing risk of censure from competition regulatory authorities. As long ago as 1988, the British Monopolies and Mergers Commission accused British Gas of abusing its dominant position by pricing gas to industrial customers with reference to oil prices. ${ }^{33}$ From a competition perspective, it may be problematic to insist that the pricing of gas to European consumers should remain subject to energy products with prices dominated on the supply side largely by the decisions of OPEC, and on the demand side largely by the dynamics of the transportation sector. Competition regulators do not have powers to require parties - and particularly parties which are not EU member states - to change the indexation in their long-term gas contracts. They may instead act to prevent utilities from passing the oil productlinked terms of those contracts downstream to their customers. In addition, they may insist that gas consumers have the freedom to buy gas at hubs as short-term gas pricing develops.

Such remedies would fit with the arguments of the second group of stakeholder views (regulators, traders and new entrants) identified by DG COMP which suggest that oillinked pricing is a function of lack of competition and that, '... with effective gas-ongas competition on liquid wholesale markets, oil indexation would disappear or be less prominent'. ${ }^{34}$ The view that oil-indexed pricing is merely a symptom of lack of competition is important because it suggests that little can be achieved simply by trying to force market players to change price indexation. The predominance of traditional long-term take-or-pay contracts with lagged oil indexation to eliminate volatility can be seen as a symptom of the domination of the gas market by large incumbent buyers and sellers. Until market players are forced into significant shortterm trading - for example by the need to balance their daily volumes which will lead (as in Britain) to the emergence of a balancing market - oil indexation is likely to remain the dominant mode of pricing and gas indexation to remain marginal. Thus the logic of this argument is not that price indexation needs to be changed from oil to

\footnotetext{
${ }^{33}$ Huggins 2006.

${ }^{34}$ EU Energy Sector Inquiry 2007, para 698, p. 220.
} 
gas in order to create a competitive market, but rather that when a competitive market emerges, oil price indexation will disappear in favour of gas indexation.

The third group of stakeholder views expressing outright opposition to continuing oil linkage believes that prices should be set by the interaction of supply and demand fundamentals. The views of this group on hub development are of some interest: ${ }^{35}$

...non-liquid hubs and the built-in flexibility in long-term gas import contracts tend to perpetuate the oil-price link. They considered that as long as incumbents do not have enough incentive to trade on existing hubs [this will compromise] the move from oil indexed to gas prices. They contended that even with greater hub liquidity hub prices would...tend to reflect oil indexation in import contracts. In general they considered that the main issue is contractual relations with gas producers and that oil indexation favours producers, if in the long run oil markets tend to be tighter than gas markets.

This reinforces the viewpoint of the second stakeholder group that oil indexation is a symptom of a much larger set of monopolistic contractual and market relationships rather than a narrow technical issue of price formation.

\subsection{Additional Arguments}

Associated gas. It is often said that because oil and gas frequently come out of the same well, the prices of the two products must therefore have a continuing relationship. This is intuitively appealing but ignores the fact that it is - or should be - the market in which the fuel is sold which determines its value. It is certainly true that a substantial volume of gas is produced in association with oil production and therefore is driven by oil price dynamics. ${ }^{36}$ However this does not mean that the sales price of that gas should be linked to oil prices.

Gas to liquids (GTL). It can be claimed that as a gas producer has the choice of producing gas or converting that gas to liquid fuels, which can be sold as transportation fuel, oil and gas prices will remain linked via GTL projects. However, not only are the numbers of GTL projects still relatively limited, but these investments tend to involve stranded gas which cannot be monetised by other means. ${ }^{37}$ GTL projects also tend to have long time-scales so that the commercial situation at the time of making an investment decision may be completely different to the position when the plant comes on stream. Thus any claims of a price connection between gas and oil products through GTL are very tenuous.

Hedging and financial instruments. Oil and gas may remain linked because large gas producers use crude oil and oil products for financial hedging; this can apply even to customers, such as ammonia producers, who are unable to physically switch between gas and oil products. While there is evidence that some large gas customers do indeed

\footnotetext{
${ }^{35}$ EU Energy Sector Inquiry 2007, paras 701-3, pp. 220-1.

${ }^{36}$ Indeed around 50 percent of UKCS gas production derives from oil which explains why, as long as oil prices remain high, UK producers may continue to produce gas even if its price falls to very low levels.

${ }^{37}$ In the case of the Qatari GTL projects, the choice was between LNG and GTL projects.
} 
use oil futures markets for hedging purposes, the commercial rationale for such a strategy is questionable. The principal objection is that customers are presumably only using oil because there is not a sufficiently deep liquid gas market in which to hedge gas prices, and that it would be much more appropriate for them to use such a market as and when it develops. But an additional strong argument is that while such options may be available for very large companies with sophisticated financial tools at their disposal, the majority of gas customers are not in this position and cannot hedge against price risk.

There is a further question raised by Wright (see below note 48) which is whether gas traders are influenced by the oil market as they go about their daily business. Since companies trading gas are almost certainly also trading oil, it may be proposed that a company would not allow the value of the two products to get too far 'out of line' with each other over a long period of time. But this is a proposition which is hard to substantiate with any empirical evidence.

Replacement costs. Many of the same companies are exploring for, and have portfolios of, gas and oil reserves. ${ }^{38}$ In the longer term, if the price of one product remains at a significant premium to the other, then companies will tend to focus their operations on the one with the higher price. While this will not impact on short-term prices, over a longer period it may have an impact on the choice of investments and hence eventual gas supplies and prices.

\section{WILL GAS PRICES NATURALLY FOLLOW OIL PRICES IN THE ABSENCE OF A FORMAL INDEX?}

One of the arguments of those who support continuing contractual linkage with oil is the empirical evidence from competitive gas markets that - even without such linkage - gas prices tend to follow the dynamics of oil prices.

\subsection{Evidence from the USA}

Key findings of an econometric study (Chart 10) published by the Energy Information Administration in 2006, which analysed WTI crude oil prices and Henry Hub natural gas prices over the period 1990-2006, were that: ${ }^{39}$

... natural gas and crude oil prices historically have had a stable relationship, despite periods where they may have appeared to decouple. The statistical evidence also supported the a priori expectation that while oil prices may influence the natural gas price, the impact of natural gas prices on the oil price is negligible...oil prices are found to influence the long run development of gas prices but are not influenced by them.

\footnotetext{
${ }^{38}$ This observation tends to apply to IOCs rather than gas independents or utilities with upstream assets.

${ }^{39}$ EIA 2006.
} 
But Foss' work casts significant doubt that this linkage will dominate the future. ${ }^{40}$ Her assessment of the potential for gas to oil product switching in the USA suggests limitations similar to those raised above in relation to Europe. Indeed she goes further to suggest that gas prices are likely to be much more affected by power demand and price dynamics, than by oil dynamics and that this may maintain US gas prices within a corridor of $\$ 3-6 / \mathrm{mmBtu}$ from which they will not be able to escape for more than a brief period for the following reasons:

- Diminishing returns from US and Canadian E\&P activity associated with prices above $\$ 6 / \mathrm{mmBtu}$;

- Demand elasticity and restructuring will limit opportunities for supply (such as LNG) which is not competitive;

- Structural changes in demand with power becoming the marginal application which will set the gas price. 'Petroleum liquids switching capacity will remain at best constant but is more likely to decline as a share of net summer generation capacity.'

Chart 10: WTI Crude Oil and Henry Hub Natural Gas Prices 19892005

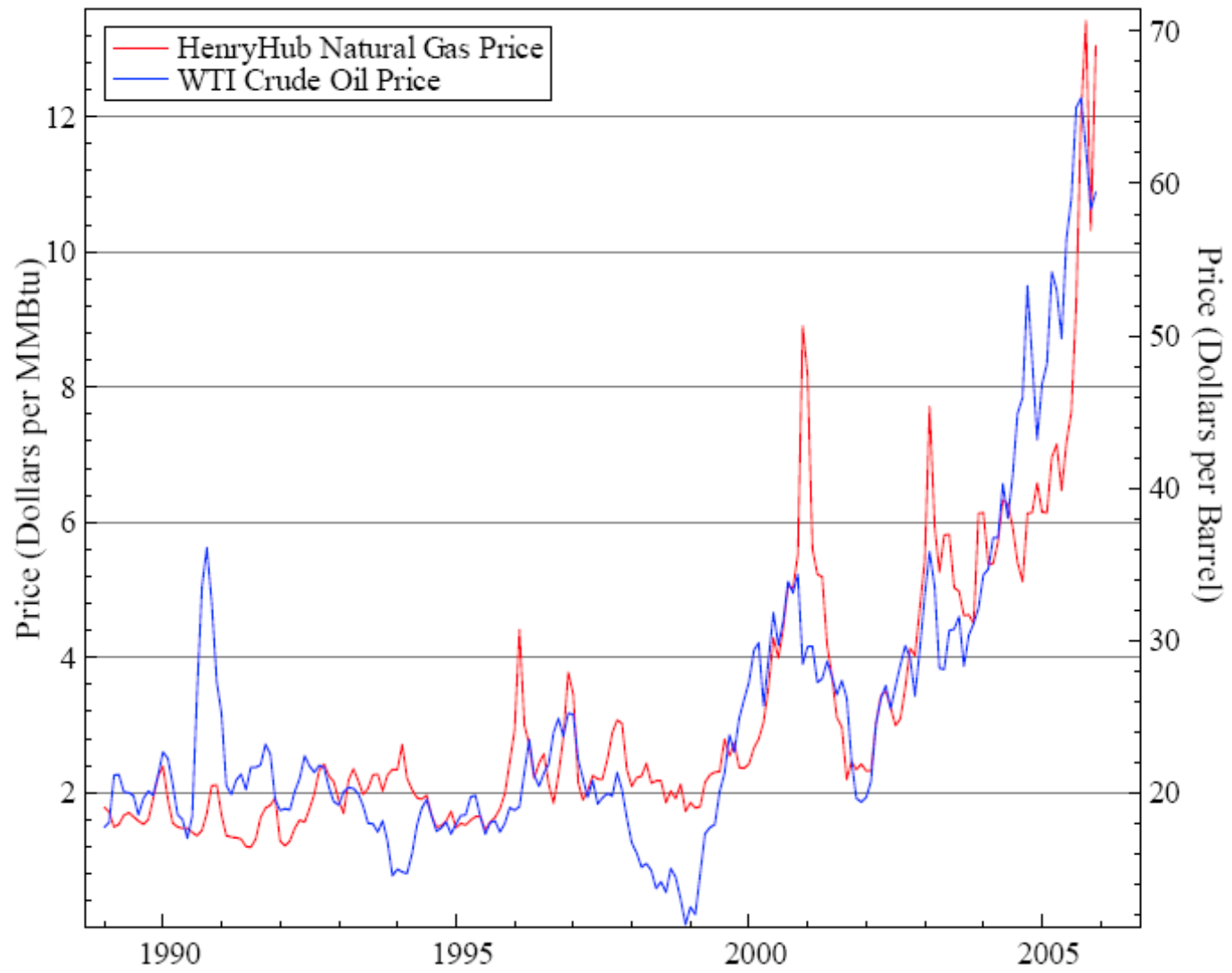

Source: EIA 2006, Figure 1

${ }^{40}$ Foss 2007. 
In summary, Foss suggests that the relationship between petroleum liquids and natural gas prices going forward will be less contingent, a function of both the dominance of natural gas production and drilling over oil, and a reflection of changing patterns of gas use.

\subsection{Evidence from the UK}

A comparison of National Balancing Point (NBP) prices with Brent crude prices (and a range of other oil and oil-linked gas prices (see Chart 11) shows that the relationship has been directionally similar during the period 1999-2006. ${ }^{41}$ Econometric work by Panagliotidis and Rutledge covering the period 1996-2003 supports this hypothesis, even prior to the establishment of the Interconnector (IUK) pipeline in 1998 through which the UK is commonly said to 'import' Continental European oil-linked prices. ${ }^{42}$ But it is not certain whether evidence from the pre-1998 period is still relevant to the modern UK gas market given very substantial changes in the commercial environment since that date. In particular, it may be that the potential for gas customers to switch to oil products was much greater pre-1998, which could have accounted for a closer price linkage with oil.

\section{Chart 11: UK Gas and International Oil Prices ${ }^{43}$}

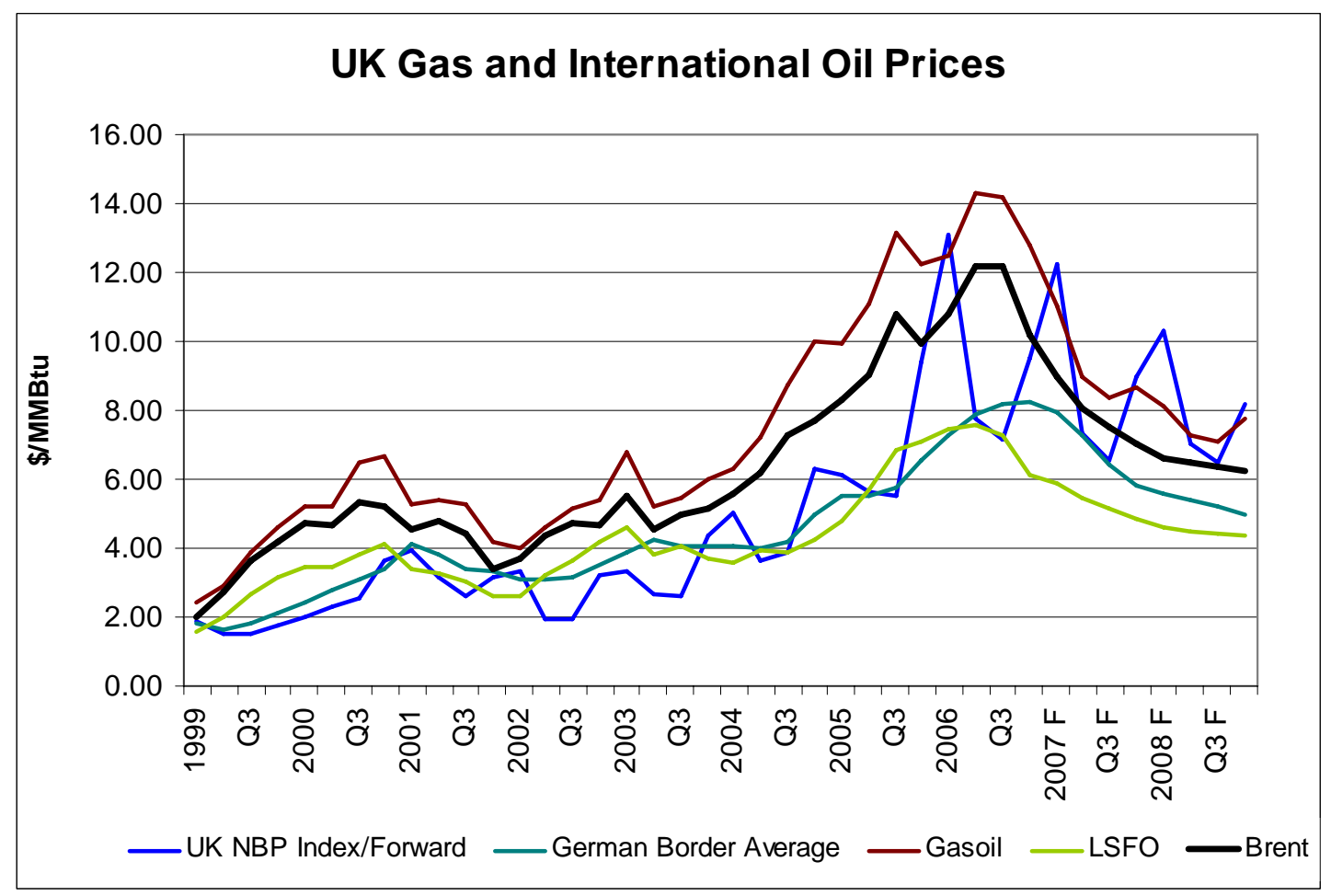

Source: Gas Strategies Online, www.gas-strategies.com

\footnotetext{
${ }^{41}$ This chart suggests that there has not only been a strong relationship in terms of historical prices but that forward prices demonstrate a similarly strong relationship.

${ }^{42}$ Panagliotidis and Rutledge 2004.

${ }^{43}$ Note the UK NBP Index/Forward corresponds to 'day ahead' prices.
} 
In a major study of UK gas prices, Wright demonstrates the complexity of these relationships and finds no relationship between front month IPE oil and gas prices, or gasoil and front month gas prices. ${ }^{44}$ For the period 1990-2005, Huggins found changing dynamics between 5-year periods: during the years 1990-1995 gas prices had a close relationship with oil prices; during the period 1995-2000 gas prices appeared to have no relationship to oil; and during the period 2000-2005, gas prices had a relationship but with a significant time lag. ${ }^{45}$

Futyan's work on the price impact of the Interconnector (IUK) pipeline finds that prior to the commissioning of the pipeline and during its first year of operation when flows were very low, 'the NBP followed a clear seasonal pattern, independent of the falling oil price. The seasonal pattern indicated gas-on-gas-competition was driving prices. ${ }^{46}$ For the period 1999-2005, Futyan identified a clear, but changing, correlation between the NBP and oil prices with direct price linkage from 1999-2001 and linkage plus seasonality from 2002-2005 (Chart 12). Also, during periods when the IUK pipeline was not operating, either due to planned maintenance or because of unplanned outages, Futyan found evidence of delinking of NBP from Zeebrugge Hub gas prices (which are dominated by the long-term oil product-linked Continental European contracts). However, these periods were not long - generally one or two weeks. ${ }^{47}$ During the winters of 2003-04, 2004-05 and 2005-06 gas price volatility showed the market had its own dynamics with actual shortage, as well as 'market sentiment' about shortage, creating substantial short-term upward pressure on prices. No definitive conclusions can be drawn from these episodes, because of their short duration, but they suggest that, freed from Continental European oil linkage, the UK market may have its own dynamics, which would support Wright's findings.

We are left with some very pertinent questions posed by Wright: ${ }^{48}$

...can it really be the case that if there were no oil-indexed gas contracts in Europe there would be no link between oil and gas prices? And how can the co-integration between spot oil and spot gas prices found by Panagliotidis and Rutledge be explained from within the oil-indexed contract paradigm?...which now leads us to consider another possibility - that gas traders who are also upstream producers directly link both their wholesale market and futures/forward trades with the oil price or, alternatively use their trading power in a way which achieves the same effect.

\footnotetext{
${ }^{44}$ Wright 2006, pp. 104-07 especially figures 4.21 and 4.22 .

${ }^{45}$ Huggins 2006.

${ }^{46}$ Futyan, p. 34.

${ }^{47}$ Futyan, p. 36.

${ }^{48}$ Wright 2006, p.111.
} 


\section{Chart 12: Phases of UK Gas and Oil Price Linkage}

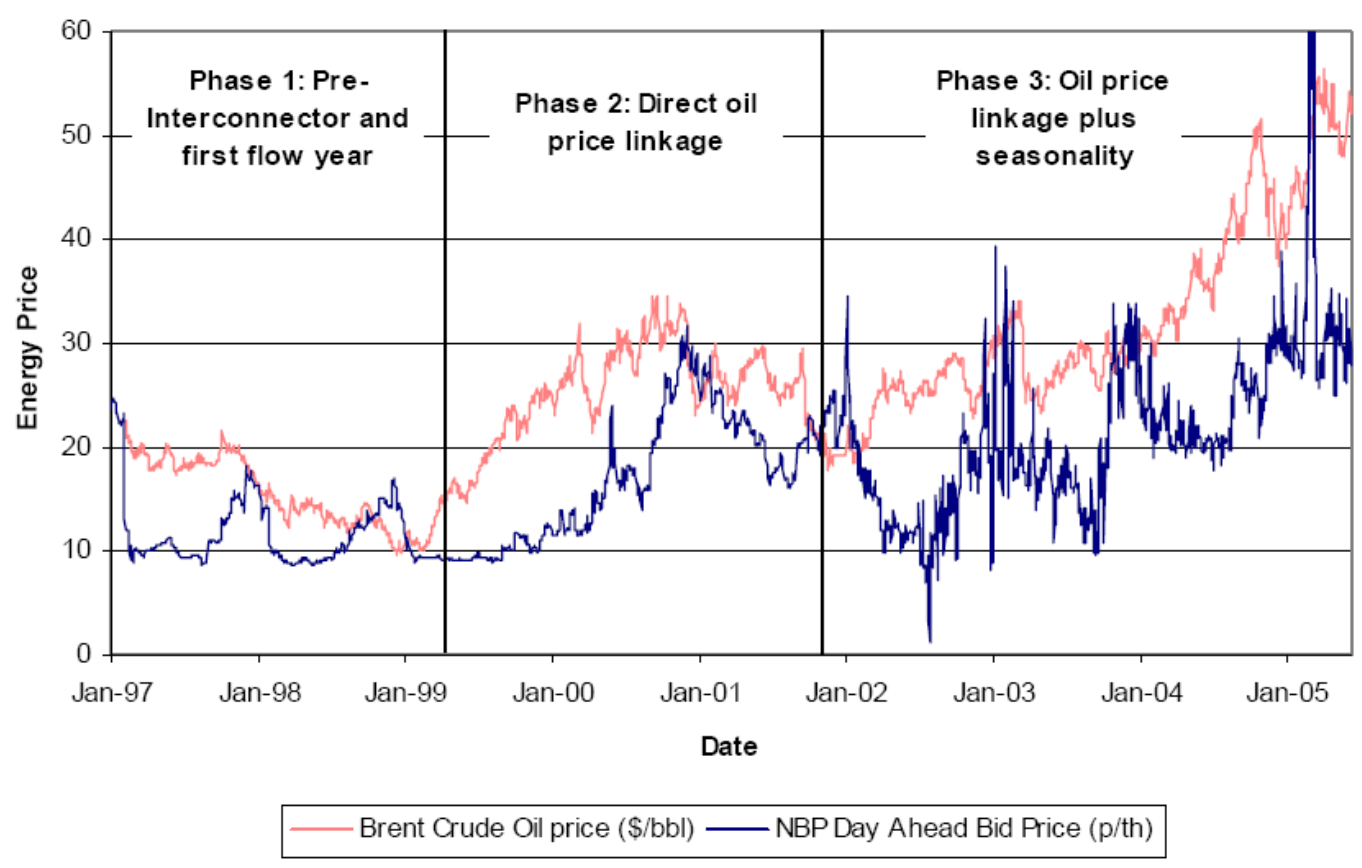

Source: Futyan, Figure 18, p. 35

Thus for the British market, the evidence as to whether there would be a link between NBP and oil prices in the absence of the influence of Continental European oil-linked prices through IUK is not conclusive; but there is reason to believe that at least such a link would be significantly less strong.

\subsection{Evidence from Continental Europe}

The DG COMP Sector Investigation Report analysed its very large sample of gas contracts comparing those with prices indexed to gas with those indexed to oil products. The results are statistically less significant than those reviewed in the cases of the USA and UK above, because of the relatively short two-year time period (January 2003-December 2004), but the report concluded: ${ }^{49}$

Long-term contracts indexed to oil are much less volatile than those indexed to hub gas prices. In this case, hub gas prices are below oil indexed prices for the majority of the analysis period, with the exception of the period November to February. The overall level of prices in oil-indexed contracts was higher than in gas-indexed contracts for most of the period. However, the short periods when oil-indexation was cheaper were also the periods of highest volume (in winter). We suspect that, on a volume-weighted basis, there was no clear commercial advantage either way.

The evidence from the US and British markets from the past decade is that over periods of 5-15 years, a strong link between gas and oil prices can be empirically observed, but that short-term gas supply and demand dynamics can separate oil and

\footnotetext{
${ }^{49}$ EU Energy Sector Inquiry 2006, paras 285 and 286.
} 
gas prices for a period of months up to several years. A possible hypothesis from an analysis of the past 10-15 years is that over such a long period, gas buyers and sellers of gas with formal contractual linkage to oil product prices may have experienced similar financial outcomes to those with indexation to Henry Hub or NBP. However, over shorter periods - perhaps lasting as long as a winter or a summer season (or even longer) - prices in contracts linked to oil products could have been fundamentally different - higher or lower - than those reflecting shortterm gas supply and demand conditions. With companies increasingly required to 'mark their contracts to market' and report their 'value at risk' to the financial community on a regular basis, it is doubtful that energy utilities will be able to ignore short-term market conditions if (or when?) hub trading in Continental Europe begins to strengthen.

One of the main advantages of retaining the current system of oil product price linkage is claimed to be the avoidance of short-term gas price volatility associated with competitive gas markets. The DG COMP study confirmed that over a two-year period January 2003-December 2004, long-term contract prices were much less volatile than hub prices. Given that oil prices also tend to be volatile, long-term contracts minimise volatility by averaging prices over a period of months with a lag of several months, to produce quarterly current prices. ${ }^{50}$

Not everybody believes this to be an advantage. A pure economic view is that volatility produces price signals which show market players the need to, for example, invest in more storage in order to avoid shortages during winter periods. The problem with this argument, with reference to the UK market, is that by the time those signals became evident in the early 2000 s lead times for new supply and storage investments meant that it was not possible to moderate prices during the period 2004-07. The discomfort felt by many British industrial customers during the winter of 2005-06when high and volatile prices caused some energy intensive users to close their plants on a temporary or permanent basis - did not persuade them that such signals were a manifestation of a successfully operating market. ${ }^{51}$

Moving to gas-indexed prices need not necessarily exclude a mechanism to moderate volatility by adopting a price reference period of several months, just as in current long-term Continental European contracts. The difference would be that the reference period would average spot gas prices, rather than oil product prices, over a period of weeks or months. However, eliminating short-term price volatility could reduce the interest of speculators in this market and hence reduce liquidity.

\section{WHAT COULD BE THE DETERMINANTS OF FUTURE GAS PRICES?}

If it is correct that even in liberalised and competitive markets gas and oil prices will remain aligned over the longer term, then abandoning formal contractual linkage between the products should not pose problems for market stakeholders. Thus a

\footnotetext{
${ }^{50}$ Quarterly long-term contract gas prices have been based typically on the average of the prices of indexed products over the previous 6-9 months with a lag of 3 months. There is anecdotal evidence that both the period of the index and the time lags are becoming shorter such that gas current prices begin to reflect more recent oil product prices.

${ }^{51}$ Mackenzie 2006.
} 
conviction that the long-term alignment of gas prices with oil prices seen in the past will be a good guide to the future, should remove the resistance of Continental European market players to moving from oil-indexed contracts to short-term prices set at market hubs. But short-term pricing would create a much more competitive gas market which is not in the interest of dominant incumbent players. And at a time of high oil prices, it will be difficult to persuade incumbents that it is in their interest to make such a change. Put another way, gas market stakeholders and the financial community may not be prepared to accept DG COMP's conclusion that 'there is no clear commercial advantage between oil indexed and gas indexed contracts' (see note 49). Because although this may be correct over a 5-10 year period, for relatively long periods of months and possibly years, prices of oil and gas may diverge significantly. Without formal contractual linkage, gas prices will have their own short-term dynamics and surplus or shortage will have a significant impact on the short-term profitability of commercial players.

A key question for the future is, if not oil product prices, what will be the most important determinants of gas prices in Europe? One possible hypothesis (which draws on Foss' recent work on US gas prices) is that long-term prices will be set by a price band where production and delivery cost define the floor, and alternative fuels in the power sector (because the latter is the principal source of incremental demand for gas) the ceiling. If gas prices remain outside that band for a period of several years, the consequences will either be insufficient supply or lack of market growth. Within the corridor, oil price linkage may be observed but will not necessarily have a positive or negative influence. Because different European countries and regions will have different gas delivery costs, and different power generation alternatives, price dynamics may vary throughout Europe. Spain will have different price dynamics to North West Europe because of that country's much greater dependence on LNG and pipeline gas from Algeria with a high degree of crude oil indexation, combined with an inability to build coal and nuclear power plants.

In North West Europe, the general level of oil prices will be a very important determinant of how long oil linkage can be sustained, because of the need to retain competitiveness in the power sector where the principal competition is coal and renewable energy (and in some countries possibly nuclear power in the longer term):

- At oil prices significantly above $\$ 30 / \mathrm{bbl}$, oil-linked gas prices are above the ceiling of the price band i.e. uncompetitive in the power sector which, in the longer term, will impact future demand which is heavily dependent on power generation. Below $\$ 30 / \mathrm{bbl}$, oil-linked gas prices will be competitive with coal (depending on the source and the environmental standards which both fuels are required to meet) and oil price linkage could continue without restricting the market share of gas.

- At oil prices significantly below $\$ 20 / \mathrm{bbl}$, i.e. below the floor of the price band, demand for gas-fired power generation will be stimulated but there will be little incentive to provide new supplies from the majority of sources. 
Thus when oil prices were in the range of $\$ 20-30 / \mathrm{bbl}$ i.e. until around 2003, oillinked pricing did not present a significant problem for the gas industry. ${ }^{52}$ Since 2003, and particularly if oil prices significantly above $\$ 30 / \mathrm{bbl}$ continue for a long period of time - as many expect - oil-linked gas prices will prevent development of gas-fired power generation, thereby eliminating significant demand growth in the majority of European markets.

Another important determinant of gas prices will be whether the market is in shortage or surplus. In a shortage it will be much easier for market players to retain oil price indexation, whereas a surplus of supply could seriously threaten oil price linkage. A combination of high oil prices and a gas surplus would place maximum pressure on market participants to move to alternative indexation. In early 2007 it seemed likely that the UK was entering several years of oversupply during which it could serve as Europe's 'clearing house' for gas, or 'offshore loading jetty' for LNG, which could be delivered to UK terminals and flow to Continental Europe using recently expanded pipeline capacity, in the Interconnector (IUK) and BBL pipelines. In this way, existing players and new entrants in Continental European markets will be able to access flexible and competitively priced supplies from the UK. Continental European utilities are able to operate a degree of arbitrage between NBP and longterm oil-indexed prices by reducing nominations of the latter when the prices of the former are more attractive. Those with LNG cargoes and regasification capacity on both sides of the Atlantic will also arbitrage NBP (and other European) prices against Henry Hub. ${ }^{53}$

Because of this range of new and diverse influences on European gas prices, it seems likely that - at a minimum - the future will be different to the past. But the dominance of 20-25 year long-term oil-indexed take-or-pay contracts between market players who have strong interests in maintaining the status quo, means that the change is unlikely to be rapid. Given the market power of these players and the fact that many contracts in force today will still be in force 10-25 years hence, the most likely outcome is a progressive introduction of spot indices in price indexation formulae leading to greater diversity of indexation applied to individual market circumstances. The speed with which this occurs may depend on two considerations:

- the ability of Continental European buyers to manage the gas surplus emerging in North West Europe in the late 2000s;

- whether dominant incumbents (buyers and sellers) will be satisfied with market conditions where - in North West Europe at least - it will be very difficult to build new gas-fired generation (and hence obtain significant market growth) while retaining oil-linked prices. As long as dominant players - suppliers and buyers - are relaxed about slow or no future market

\footnotetext{
52 For much of the 1990 s when oil prices were below $\$ 20 / \mathrm{bbl}$, costs of production and delivery from the (UK and Norwegian) North Sea, Netherlands, Russia and North Africa were low enough to allow producers significant profits and incentives to continue exploration and development. With exhaustion of reserves in the North Sea and the Netherlands and increased costs of new supplies from nonEuropean sources, this is unlikely to be the case in the 2010s. Stern 2006.

${ }^{53}$ With appropriate allowances for transportation costs.
} 
growth, they may continue to be comfortable with oil-linked pricing and resist pressure to make any rapid changes.

\section{SUMMARY AND CONCLUSIONS}

This paper has argued that the rationale for continued linkage of gas prices to those of oil products in long-term Continental European contracts is weak and will weaken further. Its original rationale - that end-users had a real choice between burning gas and oil products, and would switch to the latter if given a price incentive to do so was robust when oil product indexation was established in the late 1970s and early 1980s. But a combination of:

- the cost and inconvenience of maintaining oil-burning equipment and substantial stocks of oil products;

- the emergence of modern gas-burning equipment in which the use of oil products means a substantial loss of efficiency;

- tightening environmental standards in relation to emissions,

has rendered the original rationale increasingly dubious in the majority of countries, particularly in North West Europe. There is no likely scenario in which European energy users installing new fuel-burning equipment will choose to use oil products rather than gas in stationary uses, unless they have no access to a gas supply.

Moreover the ability of existing gas users to switch to oil products appears to be limited and declining. Of the two main oil products which comprise 80-95 percent of indexation in long-term Continental European gas contracts, gasoil has both openly quoted prices and a verifiably liquid market, but fuel oil has neither of these attributes. Without access to specialised information services, it is difficult to obtain price and volume information about fuel oil markets and prices in North West Europe.

Sales of gasoil for transportation are around twice the sales to stationary end-users. For fuel oil the position is similar for North West Europe as a whole, but in Germany and France significant quantities - in excess of volumes used in transportation - are still used in the industrial sector. This means that prices in gasoil and fuel oil markets are set by the dynamics of transportation (not stationary fuel) demand. Crude oil (and therefore derived oil products) prices are set on the supply side largely by OPEC and on the demand side largely by the dynamics of the transportation sector. Oil supply is largely irrelevant to European gas supply and, with dwindling oil product sales to the stationary sectors, oil demand is becoming progressively less relevant to gas demand.

The rationale for retaining oil-linked gas pricing is that no other acceptable indexation is available, and the dominant commercial parties - producers, exporters and incumbent utilities - are comfortable with this indexation and have sufficient

\footnotetext{
${ }^{54}$ However, they may choose to use alternatives to gas, particularly for power generation.

${ }^{55}$ Unless it is believed that natural gas will become an important fuel for transportation. Maisonnier 2006.
} 
market power to maintain it. The obvious alternative for North West Europe is indexation to gas prices based on trading at market hubs such as the British NBP. But this presents a problem given the consensus that there is insufficient liquidity at any of the Continental European hubs - even at the hub with the greatest liquidity which is the TTF in the Netherlands - to act as an acceptable index. Doubts have been expressed about the longer-term suitability of these Continental European hubs due to the likelihood that they may be dominated by one (or more) large national player. This raises the question as to whether the NBP - which is an acceptably liquid hub could serve as the gas index for the whole of the European market, or at least for North West Europe. An alternative could be an index based on a combination of prices at the NBP, TTF and Zeebrugge hubs.

As LNG becomes a larger part of European gas markets, the dynamics of international (and potentially global) pricing will feed back into national and regional markets, particularly when prices in North America and the Pacific are above those in Europe. What is uncertain - aside from Spain where LNG accounts for around twothirds of supply - is the extent to which this will be a price driver, as opposed to an influence on prices at the margin, for markets which are overwhelmingly supplied by pipeline gas.

Another important influence on future prices will be the prices of alternative fuels which are used by power generators, because if there is to be a major growth market for gas in the majority of European countries it will be the power sector. A specific price index for gas sold to power generators - with some mix of coal, power and carbon prices - seems to be indicated. But this would allow power station buyers of gas to arbitrage the spark spread, thereby depriving producers/exporters of rent, which would not be an appealing proposition for the latter.

This paper has found a clearly diminishing rationale for the continuing indexation to oil product prices in Continental European gas contracts, but this does not mean that such indexation will disappear. With oil prices in the approximate range of $\$ 20$ $30 / \mathrm{bbl}$, it will be possible to maintain oil-linked prices because this will fit into the band where the floor is set by delivery costs of new gas, and the ceiling by the price of fuels (principally coal) which compete with gas in the power sector. But at the oil price levels seen since 2003 - which many believe will continue for some years - oillinked gas prices cannot be sustained unless market players are willing to tolerate a future with little or no growth in gas demand. Even if they are willing to do so, they may struggle to maintain oil-linkage in the face of a growing surplus of supply in the late 2000 s.

Even if formal contractual linkage to oil products does disappear, this does not necessarily mean that gas prices will bear no relationship to those of oil. The term 'decoupling', often used in this context, is misleading because it suggests a complete disconnect between the prices of the two fuels; and such a development is most unlikely. In the two main markets where prices have principally been set by gas to gas competition over the past 10-15 years - the UK and North America - there has been a close long-term relationship between gas and oil prices. In the UK, this is explicable

\footnotetext{
${ }^{56}$ i.e. power generators could decide whether there was a bigger profit in burning gas for power generation or selling the same gas to the non-power sector.
} 
by the 'import' of oil-linked prices from Continental Europe through the Interconnector pipeline, but in North America it is not. Work on North American gas prices, recently published by the OIES, has concluded that electricity, rather than oil, price dynamics are likely to be a more important determinant of future gas prices. If it is believed that gas prices will 'naturally' follow those of oil, then a decision to abandon contractual linkage to oil products should not be so difficult to take. The potential problem of short-term volatility could be addressed by averaging gas (rather than oil product) prices over a quarterly reference period to produce an average.

If the dominant European gas market players accept the main proposition of this paper they are faced with a dilemma:

- should they continue to defend a commercial arrangement whose principal rationale is that no other price formation mechanism is available - with a suspicion (bordering on accusation) that this is principally because they have hindered the emergence of hubs and spot trading - since they find it commercially comfortable and are able to maintain it through a combination of inertia and market power?

- alternatively, should they move to gas-indexed contracts which would require them to choose a single liquid market hub in Continental Europe - since it is unlikely that a series of hubs in each country can attract sufficient players and sufficient liquidity to become a credible pricing reference - or use either the British NBP, or a combination of the NBP, Dutch TTF and Belgian Zeebrugge hub prices adjusted for transportation charges?

To the extent that they decide to stick to the status quo, dominant utilities can expect increasing problems from energy and competition regulators - both national and EU - in their attempts to pass through to their customers the consequences of movements in oil products, which have decreasing relevance to the markets into which their gas is being sold. If they decide to move to gas indexation, in early 2007 the NBP/TTF/Zeebrugge option seemed more likely to prevail because of (i) increasing pipeline capacity between the UK and the Continent (ii) an emerging surplus of supply in the UK which will last through (at least) the late 2000s, and the consequent ability of Continental European players to access flexible gas to balance their portfolios and (iii) the expectation that, over time, these prices will come to reflect North West European, rather than British, market dynamics.

But a theme of this paper is that a narrow focus on the rationale for continued oillinkage may risk missing the bigger commercial picture. Gas price formation may be viewed less as a product of commercial negotiations and more as a reflection of the degree of market competition. If this is correct, oil-linked pricing will disappear only when European gas markets become competitive and no longer dominated by incumbents. In early 2007, this seemed unlikely to occur either as a result of a cathartic market event or regulatory pressure from the European Commission, resulting in rapid and radical change. Instead, the gradual emergence of daily balancing markets - combined with increasing availability of flexible gas supplies from the UK - may enable new entrants, and force incumbents, to trade to a greater extent than previously and therefore promote market liquidity. Unless competition in Continental European gas markets emerges on a scale and at a speed that few currently anticipate, this will be a gradual process with oil products remaining a dominant influence on European gas prices for some time to come. 


\section{REFERENCES}

Correlje et al, 2003: Aad Correlje, Coby van der Linde, Theo Westerwoudt, Natural Gas in the Netherlands: from Cooperation to Competition, Amsterdam: OranjeNassau Group: 2003

Conant 1986: ed. Melvin A. Conant, The World Gas Trade: a Resource for the Future, Westview Press, 1986.

EIA 2006: Jose A. Villar and Frederick L. Joutz, The Relationship between Crude Oil and Natural Gas Prices, http://www.eia.doe.gov/pub/oil_gas/natural_gas/feature_articles/2006/reloilgaspri/rel oilgaspri.pdf

ECS 2007: Putting a Price on Energy: international pricing mechanisms for oil and gas, Energy Charter Secretariat, 2007.

EU Benchmarking Report 2007: Communication for the Commission to the Council and the European Parliament, Prospects for the internal gas and electricity market, Brussels January 2007.

EU Energy Sector Inquiry 2006: European Commission DG COMP, Energy Sector Inquiry, Draft Preliminary report, 16 February, 2006.

EU Energy Sector Inquiry 2007: European Commission DG Competition Report on Energy Sector Inquiry, SEC (2006) 1724, 10 January, 2007.

EU Large Combustion Plant Directive: Council Directive of 24 November 1988 on the limitation of emissions of certain pollutants into the air from large combustion plants, 88/609/EEC, Official Journal L336, 7.12.88, pp. 1-19.

Foss 2007: Michelle Michot Foss, United States Natural Gas Prices to 2015, OIES February 2007. http://www.oxfordenergy.org/pdfs/NG18.pdf

Futyan 2006: Mark Futyan, The Interconnector Pipeline: a Key Link in Europe's Gas Network, OIES, March 2006, www.oxfordenergy.org/pdfs/NG11.pdf

Hallouche 2006: Hadi Hallouche, The Gas Exporting Countries Forum: is it really a Gas OPEC in the making? June 2006, http://www.oxfordenergy.org/pdfs/NG13.pdf

Honoré 2006: Anouk Honoré, Future Natural Gas Demand in Europe: the importance of the power sector, OIES 2006, http://www.oxfordenergy.org/pdfs/NG10.pdf

Huggins 2006: John Huggins, The Accidental Link Between Gas and Oil Prices, The Business Economist, Vol 37, No 1, 2006, pp. 33-44.

IEA 1986: International Energy Agency, Natural Gas Prospects, Paris: OECD, 1986.

IEA 1991: International Energy Agency, Natural Gas: Prospects and Policies, Paris: OECD, 1991.

IEA 1998: International Energy Agency, Natural Gas Pricing in Competitive Markets: Paris: OECD, 1998.

IEA 2006: International Energy Agency, Natural Gas Information 2006, Paris: OECD, 2006. 
IEA Oil Data: data in Tables 3-7a and in Appendices A and B have been drawn from:

- IEA, Oil Information 2006 Edition (Germany - III.217-218, France - III.202203, the Netherlands - III.363-364, Belgium - III.127(gasoil)-128(fuel oil), Italy - III. 290-291), Spain - III.453-454).

- Oil Information 2004 Edition (Germany - III.217-218, France - III.202-203, the Netherlands - III.361-362, Belgium - III.127-128, Italy - III. 288-289, Spain - III.451-452).

- Oil \& Gas Information 1989-1991 (Germany - III.310-311, France - III.293294, the Netherlands - III.421-422, Belgium - III.225-226, Italy - III. 372-373, Spain - III.486-487).

- IEA Energy Balances: Energy Balances of OECD Countries. 2003-2004 (Germany - II.71, France - II.67, the Netherlands - II.111, Belgium - II.47, Italy - II.91, Spain - II.135).

Mackenzie 2006: Andrew Mackenzie, The True Cost of High Energy Prices on UK Manufacturing, National Grid Winter Outlook Seminar, November 2006.

Maisonnier 2006, Guy Maisonnier, The Ties Between Natural Gas and Oil Prices, International Association of Energy Economists' Newsletter, $3^{\text {rd }}$ Quarter 2006, pp. 26-9.

Panagliotidis and Rutledge 2004: Theodore Panagliotidis and Emilie Rutledge, Oil and Gas Markets in the UK: Evidence For From (sic) a Cointegrating Approach, Department of Economics, Loughborough University, 2004.

Stern 1984: Jonathan P. Stern, International Gas Trade in Europe: the Policies of Exporting and Importing Countries, Chapter 3, London: Heinemann, 1984.

Stern 1990: Jonathan P. Stern, European Gas Markets: Challenge and Opportunity in the 1990s, RIIA/Dartmouth, 1990.

Stern 2006: Jonathan Stern, The New Security Environment for European Gas: Worsening Geopolitics and Increasing Global Competition for LNG, OIES 2006, http://www.oxfordenergy.org/pdfs/NG15.pdf

Stern 2007: Gas-OPEC: a distraction from the important issues of Russian gas supply to Europe, Oxford Energy Comment, February 2007, http://www.oxfordenergy.org/pdfs/comment_0207-1.pdf

Wright 2006: Philip Wright, Gas Prices in the UK: Markets and Insecurity of Supply, OIES: OUP, 2006. 


\section{APPENDIX A: GASOIL AND FUEL OIL CONSUMPTION IN EUROPE}

1985-2004*

Table 1. Gas/Diesel Oil Consumption (all stationary sectors) (thousand tons)

\begin{tabular}{|l|c|c|c|c|c|c|c|}
\hline & 1998 & 1999 & 2000 & 2001 & 2002 & 2003 & 2004 \\
\hline Germany & 34899 & 29904 & 28124 & 32056 & 28673 & 28188 & 25582 \\
\hline France & 16097 & 15415 & 14054 & 16177 & 14596 & 15360 & 15404 \\
\hline Netherlands & 1137 & 1356 & 421 & 403 & 372 & 435 & 407 \\
\hline Belgium & 5578 & 5125 & 4705 & 5048 & 4429 & 4908 & 4844 \\
\hline Italy & 6073 & 6482 & 6514 & 6295 & 5986 & 5694 & 5318 \\
\hline Spain & 3790 & 4039 & 4658 & 5339 & 5235 & 5618 & 5666 \\
\hline TOTAL & 67574 & 62321 & 58476 & 65318 & 59291 & 60203 & 57221 \\
\hline
\end{tabular}

Table 2: Consumption of Gas/Diesel Oil by Industry (thousand tons)

\begin{tabular}{|l|c|c|c|c|c|c|c|c|c|c|}
\hline & 1985 & 1990 & 1995 & 1998 & 1999 & 2000 & 2001 & 2002 & 2003 & 2004 \\
\hline Germany & 4175 & 3987 & 4144 & 3369 & 3128 & 2784 & 2728 & 2769 & 2714 & 2833 \\
\hline France & 4065 & 2623 & 3285 & 3048 & 2475 & 2841 & 2832 & 2412 & 2625 & 2985 \\
\hline Netherlands & 317 & 386 & 228 & 207 & 226 & 193 & 188 & 164 & 175 & 181 \\
\hline Belgium & 304 & 273 & 428 & 615 & 514 & 423 & 761 & 406 & 304 & 292 \\
\hline Italy & 1180 & 1135 & 1392 & 1369 & 1352 & 1423 & 1129 & 1441 & 1154 & 1198 \\
\hline Spain & 384 & 442 & 494 & 875 & 925 & 1136 & 1208 & 1184 & 1318 & 1505 \\
\hline TOTAL & 10425 & 8846 & 9971 & 9483 & 8620 & 8800 & 8846 & 8376 & 8290 & 8994 \\
\hline
\end{tabular}


Table 3: Consumption of Gas/Diesel Oil by Households (thousand tons)

\begin{tabular}{|l|c|c|c|c|c|c|c|c|c|c|}
\hline & 1985 & 1990 & 1995 & 1998 & 1999 & 2000 & 2001 & 2002 & 2003 & 2004 \\
\hline Germany & 23221 & 17100 & 20997 & 22076 & 18594 & 18187 & 20872 & 18433 & 18089 & 16193 \\
\hline France & - & 8320 & 7764 & 8281 & 8442 & 7402 & 8860 & 8130 & 8350 & 8050 \\
\hline Netherlands & 272 & 165 & 95 & 53 & 50 & 22 & 23 & 22 & 24 & 24 \\
\hline Belgium & 3535 & 3184 & 3504 & 3848 & 3578 & 3551 & 3526 & 3015 & 3447 & 3410 \\
\hline Italy & 10293 & 7048 & 4761 & 4550 & 4570 & 4044 & 4480 & 3922 & 3253 & 3527 \\
\hline Spain & 1001 & 1260 & 1650 & 1800 & 1855 & 2056 & 2055 & 2015 & 2239 & 2557 \\
\hline TOTAL & 38322 & 37077 & 38771 & 40608 & 37089 & 35262 & 39816 & 35537 & 35402 & 33761 \\
\hline
\end{tabular}

Table 4: Consumption of Gas/Diesel Oil by Service (Commercial) Sector (thousand tons)

\begin{tabular}{|l|c|c|c|c|c|c|c|c|c|c|}
\hline & 1985 & 1990 & 1995 & 1998 & 1999 & 2000 & 2001 & 2002 & 2003 & 2004 \\
\hline Germany & 10009 & 9705 & 9235 & 8688 & 7492 & 6564 & 7877 & 6957 & 6827 & 6112 \\
\hline France & 15206 & 4286 & 4367 & 4733 & 4450 & 3728 & 4400 & 4007 & 4330 & 4290 \\
\hline Netherlands & - & 497 & - & 871 & 1070 & 199 & 185 & 174 & 225 & 193 \\
\hline Belgium & 830 & 895 & 1002 & 1098 & 1009 & 717 & 745 & 1001 & 1151 & 1137 \\
\hline Italy & 790 & 304 & - & 0 & 0 & 285 & 240 & 307 & 866 & 378 \\
\hline Spain & 604 & 630 & 730 & 800 & 900 & 1140 & 1290 & 1265 & 1405 & 1604 \\
\hline TOTAL & 27439 & 16317 & 15334 & 16190 & 14921 & 12633 & 14737 & 13711 & 14804 & 13714 \\
\hline
\end{tabular}


Table 5: Consumption of Gas/Diesel Oil by Transformation (power) Sector (thousand $\underline{\text { tons) }}$

\begin{tabular}{|l|c|c|c|c|c|c|c|c|}
\hline & 1990 & 1998 & 1999 & 2000 & 2001 & 2002 & 2003 & 2004 \\
\hline Germany & 884 & 766 & 690 & 589 & 579 & 514 & 558 & 444 \\
\hline France & 23 & 35 & 48 & 83 & 85 & 47 & 55 & 79 \\
\hline Netherlands & 20 & 6 & 10 & 7 & 7 & 12 & 11 & 9 \\
\hline Belgium & 3 & 17 & 24 & 14 & 16 & 7 & 6 & 5 \\
\hline Italy & 303 & 154 & 560 & 762 & 446 & 316 & 421 & 215 \\
\hline Spain & 143 & 315 & 359 & 326 & 786 & 771 & 656 & \\
\hline TOTAL & 1376 & 1293 & 1691 & 1781 & 1919 & 1667 & 1707 & 752 \\
\hline
\end{tabular}

Table 6. Fuel Oil Consumption (all stationary sectors) (thousand tons)

\begin{tabular}{|l|c|c|c|c|c|c|c|}
\hline & 1998 & 1999 & 2000 & 2001 & 2002 & 2003 & 2004 \\
\hline Germany & 5449 & 4700 & 5492 & 6000 & 5942 & 5599 & 5429 \\
\hline France & 5374 & 4484 & 3891 & 3600 & 3148 & 3326 & 3049 \\
\hline Netherlands & 72 & 62 & 52 & 99 & 21 & 49 & 57 \\
\hline Belgium & 1402 & 1209 & 842 & 1151 & 695 & 1237 & 1160 \\
\hline Italy & 25431 & 23036 & 21669 & 19666 & 21114 & 20022 & 15061 \\
\hline Spain & 6105 & 7124 & 6450 & 6512 & 7444 & 6541 & 6296 \\
\hline TOTAL & 43833 & 40615 & 38396 & 37028 & 38364 & 36774 & 31052 \\
\hline
\end{tabular}


Table 7: $\underline{\text { Consumption of Residual Fuel Oil by Industry (thousand tons) }}$

\begin{tabular}{|l|c|c|c|c|c|c|c|c|c|c|}
\hline & 1985 & 1990 & 1995 & 1998 & 1999 & 2000 & 2001 & 2002 & 2003 & 2004 \\
\hline Germany & 7592 & 4752 & 4352 & 3058 & 2431 & 4096 & 4342 & 4741 & 4218 & 3749 \\
\hline France & 4798 & 3363 & 2814 & 2307 & 1803 & 1818 & 1885 & 1845 & 1691 & 1730 \\
\hline Netherlands & 631 & 178 & 104 & 60 & 44 & 41 & 44 & 6 & 21 & 19 \\
\hline Belgium & 1509 & 1252 & 1003 & 952 & 885 & 669 & 871 & 493 & 849 & 696 \\
\hline Italy & 7309 & 4607 & 3280 & 3055 & 4029 & 3630 & 3176 & 3451 & 3626 & 3475 \\
\hline Spain & 5184 & 3769 & 4130 & 2602 & 1862 & 1743 & 1649 & 1745 & 1735 & 1085 \\
\hline TOTAL & 27023 & 17921 & 15683 & 12034 & 11054 & 11997 & 11967 & 12281 & 12140 & 10754 \\
\hline
\end{tabular}

Table 8: $\underline{\text { Consumption of Residual Fuel Oil by Households (thousand tons) }}$

\begin{tabular}{|l|c|c|c|c|c|c|c|c|c|c|}
\hline & 1985 & 1990 & 1995 & 1998 & 1999 & 2000 & 2001 & 2002 & 2003 & 2004 \\
\hline Germany & 592 & - & - & 0 & 0 & - & - & - & - & - \\
\hline France & - & 984 & 533 & 608 & 620 & 580 & 540 & 329 & 404 & 267 \\
\hline Netherlands & - & - & - & 0 & 0 & - & - & - & - & - \\
\hline Belgium & 38 & 8 & - & 0 & 0 & - & - & - & - & - \\
\hline Italy & 1418 & 435 & 120 & 224 & 365 & 330 & 350 & 335 & 328 & 259 \\
\hline Spain & 25 & 15 & 40 & 29 & 90 & 87 & 87 & 102 & 122 & 63 \\
\hline TOTAL & 2073 & 1442 & 693 & 861 & 1075 & 997 & 977 & 766 & 854 & 589 \\
\hline
\end{tabular}

Table 9: Consumption of Residual Fuel Oil by Service (Commercial) Sector (thousand tons)

\begin{tabular}{|l|c|c|c|c|c|c|c|c|c|c|}
\hline & 1985 & 1990 & 1995 & 1998 & 1999 & 2000 & 2001 & 2002 & 2003 & 2004 \\
\hline Germany & 547 & 231 & 149 & 125 & 204 & - & - & - & - & - \\
\hline France & 1713 & 546 & 256 & 349 & 363 & 300 & 290 & 164 & 190 & 98 \\
\hline Netherlands & - & 32 & - & 0 & 0 & 2 & 27 & - & - & 21 \\
\hline Belgium & 65 & 110 & 80 & 56 & 56 & 11 & 19 & 36 & 124 & 17 \\
\hline Italy & 450 & - & - & 0 & 0 & - & - & - & - & - \\
\hline Spain & 235 & 230 & 518 & 370 & 338 & 315 & 296 & 288 & 304 & 257 \\
\hline TOTAL & 3010 & 1149 & 1003 & 900 & 961 & 628 & 632 & 488 & 618 & 393 \\
\hline
\end{tabular}


Table 10: Consumption of Residual Fuel Oil by Transformation (power) Sector (thousand tons)

\begin{tabular}{|l|c|c|c|c|c|c|c|c|}
\hline & 1990 & 1998 & 1999 & 2000 & 2001 & 2002 & 2003 & 2004 \\
\hline Germany & 3147 & 2266 & 2065 & 1396 & 1658 & 1201 & 1381 & 1680 \\
\hline France & 1657 & 2110 & 1698 & 1193 & 885 & 810 & 1041 & 954 \\
\hline Netherlands & 276 & 12 & 18 & 9 & 28 & 15 & 28 & 17 \\
\hline Belgium & 254 & 394 & 268 & 162 & 261 & 166 & 264 & 447 \\
\hline Italy & 21798 & 22152 & 18642 & 17709 & 16140 & 17328 & 16068 & 11327 \\
\hline Spain & 2126 & 3104 & 4834 & 4305 & 4480 & 5309 & 4380 & 4891 \\
\hline TOTAL & 29258 & 30038 & 27525 & 24774 & 23452 & 24829 & 23162 & 19316 \\
\hline
\end{tabular}

* The data in these tables are from "IEA Oil Data" (see bibliography) 


\section{APPENDIX B: YEAR TO YEAR CHANGES IN GASOIL AND FUEL OIL CONSUMPTION IN EUROPE 1985-2004*}

Table 1. Year to Year Changes in Consumption of Gas/Diesel Oil by All Stationary Sectors (thousand tons)

\begin{tabular}{|l|c|c|c|c|c|c|}
\hline & $\begin{array}{l}\mathbf{1 9 9 9 -} \\
\mathbf{1 9 9 8}\end{array}$ & $\begin{array}{l}\mathbf{2 0 0 0 -} \\
\mathbf{1 9 9 9}\end{array}$ & $\begin{array}{l}\mathbf{2 0 0 1 -} \\
\mathbf{2 0 0 0}\end{array}$ & $\begin{array}{l}\mathbf{2 0 0 2 -} \\
\mathbf{2 0 0 1}\end{array}$ & $\begin{array}{l}\mathbf{2 0 0 3 -} \\
\mathbf{2 0 0 2}\end{array}$ & $\begin{array}{l}\mathbf{2 0 0 4 -} \\
\mathbf{2 0 0 3}\end{array}$ \\
\hline Germany & -4995 & -1780 & 3932 & -3383 & -485 & -2606 \\
\hline France & -682 & -1361 & 2123 & -1581 & 764 & 44 \\
\hline Netherlands & 219 & -935 & -18 & -31 & 63 & -28 \\
\hline Belgium & -453 & -420 & 343 & -619 & 479 & -64 \\
\hline Italy & 409 & 32 & -219 & -309 & -292 & -376 \\
\hline Spain & 249 & 619 & 681 & -104 & 383 & 48 \\
\hline TOTAL & -5253 & -3845 & 6842 & -6027 & 912 & -2982 \\
\hline
\end{tabular}

Table 2: Year to Year Changes in Consumption of Gas/Diesel Oil by Industry (thousand tons)

\begin{tabular}{|c|c|c|c|c|c|c|c|c|c|}
\hline & $\begin{array}{l}1985- \\
1990\end{array}$ & $\begin{array}{l}1990- \\
1995\end{array}$ & $\begin{array}{l}1995- \\
2000\end{array}$ & $\begin{array}{l}1999- \\
1998\end{array}$ & $\begin{array}{l}2000- \\
1999\end{array}$ & $\begin{array}{l}2001- \\
2000\end{array}$ & $\begin{array}{l}2002- \\
2001\end{array}$ & $\begin{array}{l}2003- \\
2002\end{array}$ & $\begin{array}{l}2004- \\
2003\end{array}$ \\
\hline Germany & -188 & 157 & -1360 & -241 & -344 & -56 & 41 & -55 & 119 \\
\hline France & -1442 & 662 & -444 & -573 & 366 & -9 & -420 & 213 & 360 \\
\hline Netherlands & 69 & -158 & -35 & 19 & -33 & -5 & -24 & 11 & 6 \\
\hline Belgium & -31 & 155 & -5 & -101 & -91 & 338 & -355 & -102 & -12 \\
\hline Italy & -45 & 257 & 31 & -17 & 71 & -294 & 312 & -287 & 44 \\
\hline Spain & 58 & 52 & 642 & 50 & 211 & 72 & -24 & 134 & 187 \\
\hline TOTAL & -1579 & 1125 & -1171 & -863 & 180 & 46 & -470 & -86 & 704 \\
\hline
\end{tabular}


Table 3: Year to Year Changes in Consumption of Gas/Diesel Oil by Households (thousand tons)

\begin{tabular}{|l|c|c|c|c|c|c|c|c|c|}
\hline & $\begin{array}{l}\mathbf{1 9 8 5}- \\
\mathbf{1 9 9 0}\end{array}$ & $\begin{array}{l}\mathbf{1 9 9 0 -} \\
\mathbf{1 9 9 5}\end{array}$ & $\begin{array}{l}\mathbf{1 9 9 5 -} \\
\mathbf{2 0 0 0}\end{array}$ & $\begin{array}{l}\mathbf{1 9 9 9 -} \\
\mathbf{1 9 9 8}\end{array}$ & $\begin{array}{l}\mathbf{2 0 0 0 -} \\
\mathbf{1 9 9 9}\end{array}$ & $\begin{array}{l}\mathbf{2 0 0 1 -} \\
\mathbf{2 0 0 0}\end{array}$ & $\begin{array}{l}\mathbf{2 0 0 2}- \\
\mathbf{2 0 0 1}\end{array}$ & $\begin{array}{l}\mathbf{2 0 0 3 -} \\
\mathbf{2 0 0 2}\end{array}$ & $\begin{array}{l}\mathbf{2 0 0 4} \\
\mathbf{2 0 0 3}\end{array}$ \\
\hline Germany & -6121 & 3897 & -2810 & -3482 & -407 & 2685 & -2439 & -344 & -1896 \\
\hline France & 8320 & -556 & -362 & 161 & -1040 & 1458 & -730 & 220 & -300 \\
\hline Netherlands & -107 & -70 & -73 & -3 & -28 & 1 & -1 & 2 & 0 \\
\hline Belgium & -351 & 320 & 47 & -270 & -27 & -25 & -511 & 432 & -37 \\
\hline Italy & -3245 & -2287 & -717 & 20 & -526 & 436 & -558 & -669 & 274 \\
\hline Spain & 259 & 390 & 406 & 55 & 201 & -1 & -40 & 224 & 318 \\
\hline TOTAL & -1245 & 1694 & -3509 & -3519 & -1827 & 4554 & -4279 & -135 & -1641 \\
\hline
\end{tabular}

Table 4: Year to Year Changes in Consumption of Gas/Diesel Oil by Service (Commercial) Sector (thousand tons)

\begin{tabular}{|c|c|c|c|c|c|c|c|c|c|}
\hline & $\begin{array}{l}1985- \\
1990\end{array}$ & $\begin{array}{l}1990- \\
1995\end{array}$ & $\begin{array}{l}1995- \\
2000\end{array}$ & $\begin{array}{l}1999- \\
1998\end{array}$ & $\begin{array}{l}2000- \\
1999\end{array}$ & $\begin{array}{l}2001- \\
2000\end{array}$ & $\begin{array}{l}2002- \\
2001\end{array}$ & $\begin{array}{l}2003- \\
2002\end{array}$ & $\begin{array}{l}2004- \\
2003\end{array}$ \\
\hline Germany & -304 & -470 & -2671 & -1196 & -928 & 1313 & -920 & -130 & -715 \\
\hline France & -10920 & 81 & -639 & -283 & -722 & 672 & -393 & 323 & -40 \\
\hline Netherlands & 497 & -497 & 199 & 199 & -871 & -14 & -11 & 51 & -32 \\
\hline Belgium & 65 & 107 & -285 & -89 & -292 & 28 & 256 & 150 & -14 \\
\hline Italy & -486 & -304 & 285 & 0 & 285 & -45 & 67 & 559 & -488 \\
\hline Spain & 26 & 100 & 410 & 100 & 240 & 150 & -25 & 140 & 199 \\
\hline TOTAL & -11122 & -983 & -2701 & -1269 & -2288 & 2104 & -1026 & 1093 & -1090 \\
\hline
\end{tabular}


Table 5: Year to Year Changes in Consumption of Gas/Diesel Oil by Power Sector (thousand tons)

\begin{tabular}{|l|c|c|c|c|c|c|c|}
\hline & $\begin{array}{l}\mathbf{1 9 9 0 -} \\
\mathbf{2 0 0 2}\end{array}$ & $\begin{array}{l}\mathbf{1 9 9 9 -} \\
\mathbf{1 9 9 8}\end{array}$ & $\begin{array}{l}\mathbf{2 0 0 0 -} \\
\mathbf{1 9 9 9}\end{array}$ & $\begin{array}{l}\mathbf{2 0 0 1 -} \\
\mathbf{2 0 0 0}\end{array}$ & $\begin{array}{l}\mathbf{2 0 0 2 -} \\
\mathbf{2 0 0 1}\end{array}$ & $\begin{array}{l}\mathbf{2 0 0 3 -} \\
\mathbf{2 0 0 2}\end{array}$ & $\begin{array}{l}\mathbf{2 0 0 4} \\
\mathbf{2 0 0 3}\end{array}$ \\
\hline Germany & -370 & -76 & -101 & -10 & -65 & 44 & -114 \\
\hline France & 24 & 13 & 35 & 2 & -38 & 8 & 24 \\
\hline $\begin{array}{l}\text { Netherla } \\
\text { nds }\end{array}$ & -8 & 4 & -3 & 0 & 5 & -1 & -2 \\
\hline Belgium & 4 & 7 & -10 & 2 & -9 & -1 & -1 \\
\hline Italy & 13 & 406 & 202 & -316 & -130 & 105 & -206 \\
\hline Spain & 628 & 44 & -33 & 460 & -15 & -115 & -656 \\
\hline TOTAL & 291 & 398 & 90 & 138 & -252 & 40 & -955 \\
\hline
\end{tabular}

Table 6. Year to Year Changes in Consumption of Fuel Oil by All Stationary Sectors (thousand tons)

\begin{tabular}{|l|c|c|c|c|c|c|}
\hline & $\begin{array}{l}\mathbf{1 9 9 9 -} \\
\mathbf{1 9 9 8}\end{array}$ & $\begin{array}{l}\mathbf{2 0 0 0 -} \\
\mathbf{1 9 9 9}\end{array}$ & $\begin{array}{l}\mathbf{2 0 0 1 -} \\
\mathbf{2 0 0 0}\end{array}$ & $\begin{array}{l}\mathbf{2 0 0 2 -} \\
\mathbf{2 0 0 1}\end{array}$ & $\begin{array}{l}\mathbf{2 0 0 3 -} \\
\mathbf{2 0 0 2}\end{array}$ & $\begin{array}{l}\mathbf{2 0 0 4} \\
\mathbf{2 0 0 3}\end{array}$ \\
\hline Germany & -749 & 792 & 508 & -58 & -343 & -170 \\
\hline France & -890 & -593 & -291 & -452 & 178 & -277 \\
\hline Netherlands & -10 & -10 & 47 & -78 & 28 & 8 \\
\hline Belgium & -193 & -367 & 309 & -456 & 542 & -77 \\
\hline Italy & -2395 & -1367 & -2003 & 1448 & -1092 & -4961 \\
\hline Spain & 1019 & -674 & 62 & 932 & -903 & -245 \\
\hline TOTAL & -3218 & -2219 & -1368 & 1336 & -1590 & -5722 \\
\hline
\end{tabular}


Table 7: Year to Year Changes in Consumption of Residual Fuel Oil by Industry (thousand tons)

\begin{tabular}{|l|c|c|c|c|c|c|c|c|c|}
\hline & $\mathbf{1 9 8 5 -}$ & $\mathbf{1 9 9 0 -}$ & $\mathbf{1 9 9 5 -}$ & $\mathbf{1 9 9 9 -}$ & $\mathbf{2 0 0 0 -}$ & $\mathbf{2 0 0 1 -}$ \\
$\mathbf{1 9 9 0}$ & $\mathbf{1 9 9 5}$ & $\mathbf{2 0 0 0}$ & $\mathbf{1 9 9 8}$ & $\mathbf{1 9 9 9}$ & $\mathbf{2 0 0 2}$ \\
$\mathbf{2 0 0 1}$ & $\begin{array}{l}\mathbf{2 0 0 3 -} \\
\mathbf{2 0 0 2}\end{array}$ & $\begin{array}{l}\mathbf{2 0 0 4} \\
\mathbf{2 0 0 3}\end{array}$ \\
\hline Germany & -2840 & -400 & -256 & -627 & 1665 & 246 & 399 & -523 & -469 \\
\hline France & -1435 & -549 & -996 & -504 & 15 & 67 & -40 & -154 & 39 \\
\hline Netherlands & -453 & -74 & -63 & -16 & -3 & 3 & -38 & 15 & -2 \\
\hline Belgium & -257 & -249 & -334 & -67 & -216 & 202 & -378 & 356 & -153 \\
\hline Italy & -2702 & -1327 & 350 & 974 & -399 & -454 & 275 & 175 & -151 \\
\hline Spain & -1415 & 361 & -2387 & -740 & -119 & -94 & 96 & -10 & -650 \\
\hline TOTAL & -9102 & -2238 & -3686 & -980 & 943 & -30 & 314 & -141 & -1386 \\
\hline
\end{tabular}

Table 8: Year to Year Changes in Consumption of Residual Fuel Oil by Households (thousand tons)

\begin{tabular}{|l|c|c|c|c|c|c|c|c|c|}
\hline & $\begin{array}{c}1985- \\
1990\end{array}$ & $\begin{array}{c}1990- \\
1995\end{array}$ & $\begin{array}{c}1995- \\
2000\end{array}$ & $\begin{array}{c}1999- \\
1998\end{array}$ & $\begin{array}{c}2000- \\
1999\end{array}$ & $\begin{array}{c}2001- \\
2000\end{array}$ & $\begin{array}{c}2002- \\
2001\end{array}$ & $\begin{array}{c}2003- \\
2002\end{array}$ & $\begin{array}{c}2004- \\
2003\end{array}$ \\
\hline Germany & -592 & 0 & & 0 & 0 & 0 & 0 & 0 & 0 \\
\hline France & 984 & -451 & & 12 & -40 & -40 & -211 & 75 & -137 \\
\hline Netherlands & 0 & 0 & & 0 & 0 & 0 & 0 & 0 & 0 \\
\hline Belgium & -30 & -8 & & 0 & 0 & 0 & 0 & 0 & 0 \\
\hline Italy & -983 & -315 & & 141 & -35 & 20 & -15 & -7 & -69 \\
\hline Spain & -10 & 25 & & 61 & -3 & 0 & 15 & 20 & -59 \\
\hline TOTAL & -631 & -749 & & 214 & -78 & -20 & -211 & 88 & -265 \\
\hline
\end{tabular}


Table 9: Year to Year Changes in Consumption of Residual Fuel Oil by Service (Commercial) Sector (thousand tons)

\begin{tabular}{|l|c|c|c|c|c|c|c|c|c|}
\hline & $\begin{array}{l}\mathbf{1 9 8 5}- \\
\mathbf{1 9 9 0}\end{array}$ & \begin{tabular}{l}
$\mathbf{1 9 9 0} \mathbf{1 9 9 5}$ \\
\hline Germany
\end{tabular} & $\begin{array}{l}\mathbf{1 9 9 5}- \\
\mathbf{2 0 0 0}\end{array}$ & $\begin{array}{l}\mathbf{1 9 9 9 -} \\
\mathbf{1 9 9 8}\end{array}$ & $\begin{array}{l}\mathbf{2 0 0 0 -} \\
\mathbf{1 9 9 9}\end{array}$ & $\begin{array}{l}\mathbf{2 0 0 1 -} \\
\mathbf{2 0 0 0}\end{array}$ & $\begin{array}{l}\mathbf{2 0 0 2}- \\
\mathbf{2 0 0 1}\end{array}$ & $\begin{array}{l}\mathbf{2 0 0 3 -} \\
\mathbf{2 0 0 2}\end{array}$ & $\begin{array}{l}\mathbf{2 0 0 4}- \\
\mathbf{2 0 0 3}\end{array}$ \\
\hline France & -1167 & -290 & 44 & 14 & -63 & -10 & -126 & 26 & -92 \\
\hline Netherlands & 32 & -32 & 2 & 0 & 2 & 25 & -27 & 0 & 21 \\
\hline Belgium & 45 & -30 & -69 & 0 & -45 & 8 & 17 & 88 & -107 \\
\hline Italy & -450 & 0 & 0 & 0 & 0 & 0 & 0 & 0 & 0 \\
\hline Spain & -5 & 288 & -203 & -32 & -23 & -19 & -8 & 16 & -47 \\
\hline TOTAL & -1861 & -146 & -375 & 61 & -333 & 4 & -144 & 130 & -225 \\
\hline
\end{tabular}

Table 10: Year to Year Changes in Consumption of Residual Fuel Oil by Power Sector (thousand tons)

\begin{tabular}{|l|c|c|c|c|c|c|c|}
\hline & $\mathbf{1 9 9 0 -}$ & $\mathbf{1 9 9 9 -}$ & $\mathbf{2 0 0 0 -}$ & $\mathbf{2 0 0 1 -}$ & $\mathbf{2 0 0 2 -}$ & $\mathbf{2 0 0 3 -}$ \\
$\mathbf{2 0 0 2}$ & $\mathbf{1 9 9 8}$ & $\mathbf{1 9 9 9}$ & $\mathbf{2 0 0 0}$ & $\mathbf{2 0 0 1}$ & $\begin{array}{l}\mathbf{2 0 0 4}- \\
\mathbf{2 0 0 3}\end{array}$ \\
\hline Germany & -1946 & -201 & -669 & 262 & -457 & 180 & 299 \\
\hline France & -847 & -412 & -505 & -308 & -75 & 231 & -87 \\
\hline Netherlands & -261 & 6 & -9 & 19 & -13 & 13 & -11 \\
\hline Belgium & -88 & -126 & -106 & 99 & -95 & 98 & 183 \\
\hline Italy & -4470 & -3510 & -933 & -1569 & 1188 & -1260 & -4741 \\
\hline Spain & 3183 & 1730 & -529 & 175 & 829 & -929 & 511 \\
\hline TOTAL & -4429 & -2513 & -2751 & -1322 & 1377 & -1667 & -3846 \\
\hline
\end{tabular}

* The data in these tables are from 'IEA Oil Data' (see bibliography) 